\title{
Sea surface temperature in continental and insular coastal Colombian waters: observations of the recent past and near-term numerical projections
}

\author{
Nancy Villegas $^{1} \mathbb{D}$, Igor Malikov ${ }^{2} \mathbb{D}$ \& Riccardo Farneti ${ }^{3}(\mathbb{D})$ \\ ${ }^{1}$ Universidad Nacional de Colombia, Bogotá, Colombia \\ ${ }^{2}$ Grupo de investigación en oceanología CENIT, Bogotá, Colombia \\ ${ }^{3}$ The Abdus Salam International Centre for Theoretical Physics (ICTP), Trieste, Italy \\ Corresponding author: Nancy Villegas (nlvillegasb@unal.edu.co)
}

\begin{abstract}
Sea surface temperature (SST) simulation for the 1970-2007 period and its projection up to 2035 was carried out with the Regional Ocean Modeling System (ROMS) for the Colombian Caribbean Sea (CCS) and the Colombian Pacific Basin (CPB). Spatial bias using the International Comprehensive Ocean-Atmosphere Data Sets (ICOADS) and Operational Sea Surface Temperature and Sea Ice Analysis (OSTIA) for 1982-2007 shows an adequate representation of surface characteristics in both marine study regions, especially on the CPB. The 1970-2007 period's deviation measures reveal a good fit between ICOADS data and simulated SST. The spatial distribution of linear multi-annual regression (ICOADS 1970-2007) evidences a similar positive trend in both regions $\left(0.01^{\circ} \mathrm{C} \mathrm{yr}^{-1}\right)$. Differences in the spatial distribution of trends between the two regions (ROMS 2008-2035) prescribe that general warming of CCS will be less $\left(0.01^{\circ} \mathrm{C} \mathrm{yr}^{-1}\right)$ than that of $\mathrm{CPB}\left(0.02^{\circ} \mathrm{C} \mathrm{yr}^{-1}\right)$. The average SST trend in waters close to continental and insular coastal stations of CCS and CPB obtained from ICOADS (1970-2015) are 0.016 and $0.013^{\circ} \mathrm{C} \mathrm{yr}^{-1}$, respectively. The average trend in the same stations obtained

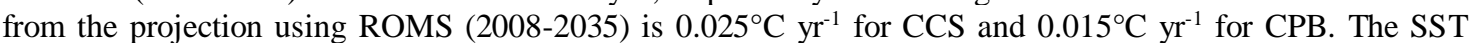
projection for 2008-2035 in the CCS shows the highest SST increase slope in waters near Punta Gallinas and in the CPB it is evidenced in waters near Malpelo Island.
\end{abstract}

Keywords: Caribbean; Pacific; sea surface temperature; trends; global warming; ROMS

\section{INTRODUCTION}

The coastal zones are one of the sectors most vulnerable to global warming, for this reason, it is vital to know as much as possible about the changes in oceanographic parameters that may be affected by different elements in the future. According to the Intergovernmental Panel on Climate Change (IPCC 2014), almost $50 \%$ of the observed increment in the sea level (SL) rises due to thermal expansion. Moreover, by the end of the 21st century, the increase in average air temperature (Ta) compared to 1850 will probably exceed $1.5^{\circ} \mathrm{C}$, and the oceans will experience continuous heating due to their high storage capacity and energy transport.

In addition to being influenced by these global processes, the coasts of both the Colombian Caribbean Sea (CCS) and the Colombian Pacific Basin (CPB) (Fig. 1) are affected by regional and local processes
(Forsbergh 1969, Stevenson 1970, CCCP 2002, Andrade 2015, Maldonado et al. 2016, Trojer 2017, Ricaurte-Villota \& Bastidas-Salamanca 2017, among others), which have their repercussions as regards the variability of thermohaline and dynamic characteristics. The extensive maritime territory of Colombia, of which the Caribbean represents $28.5 \%$ and the Pacific $16.4 \%$ of its total (CCO 2015), brings its heat and humidity to the climate variability of the inner land (Eslava 1993), meaning that any change in the characteristics of CCS or CPB waters, be it in the short, medium, or long term, would directly affect both the climate of Colombia and its inhabitants.

Complex spatial and temporal features characterize the climate of Colombian marine regions due to the interaction of regional and basin-scale atmospheric systems, combined with local effects caused by the sealand boundary. One of these atmospheric systems is the Intertropical Convergence Zone (ITCZ) that moves from

Corresponding editor: Marcel Ramos 


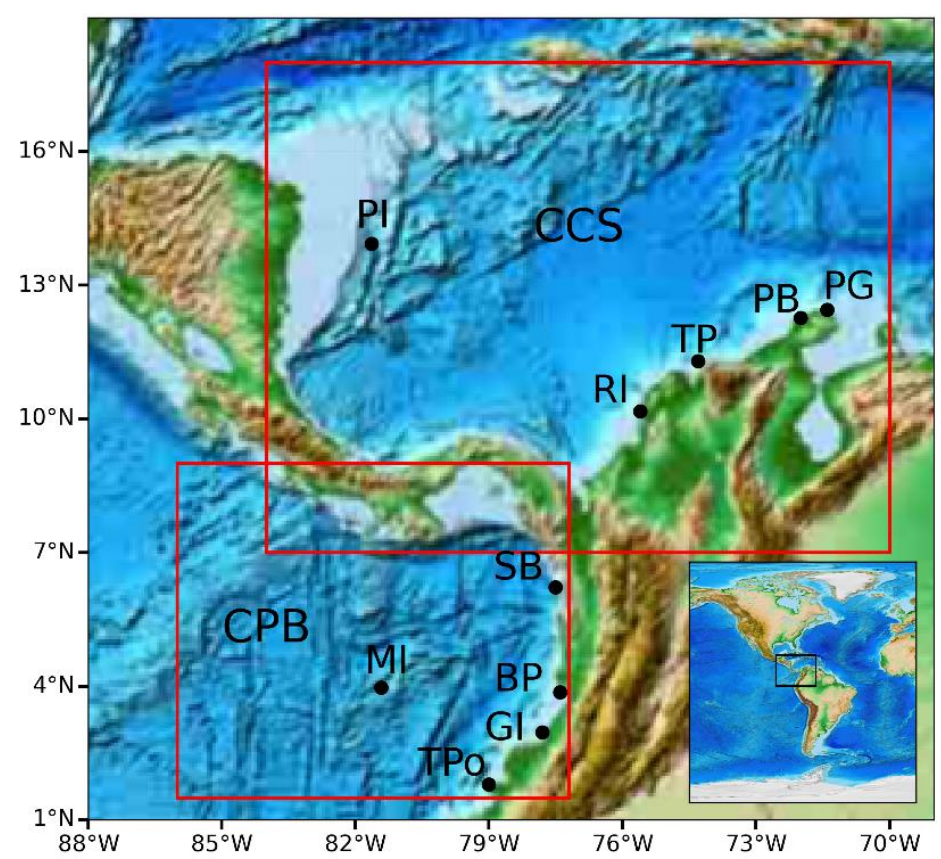

Figure 1. Study areas and selected stations. CCS: Colombian Caribbean Sea, CPB: Colombian Pacific Basin, PG: Punta Gallinas, PB: Portete Bay, TP: Tayrona Park, RI: Rosario Island, PI: Providencia Island, SB: Solano Bay, BP: Buenaventura Port, GI: Gorgona Island, TPo: Tumaco Port, MI: Malpelo Island. The location of study areas is delimited in a black box. Simulation domains are delimited in red boxes.

approximately $10^{\circ} \mathrm{N}$ in June-September to $2-5^{\circ} \mathrm{N}$ in December-March (Strub et al. 1998), as shown schematically in Figure 2a, positioning itself in the northern hemisphere in the annual average (Donohoe et al. 2013). Among the ITCZ, there are two low-level jets, one easterly over the Caribbean (CLLJ) around 10$12^{\circ} \mathrm{N}$ (Magaña et al. 1999), and the other, the Choco Low-Level Jet (ChLLJ), westerly at $\sim 5^{\circ} \mathrm{N}$ over the Pacific (Poveda \& Mesa 2000).

The circulation in the CCS (Fig. 2b) is dominated by the Caribbean Current (CC), which flows northwestward through the study area from the east (Andrade 2015). Over the Mosquitos Gulf is located the Colombia-Panama Gyre (CPG), which flows counterclockwise (Andrade et al. 2003), enclosing warm waters in the southwest of the Caribbean Sea (Pareja et al. 2013). From this part of the region, the Panama Colombia Counter Current (PCCC) flows easterly along the Colombian coast clockwise (Andrade et al. 2003). The PCCC carries warm waters forming a mixing zone when approaching the Magdalena River's mouth around $78^{\circ} \mathrm{W}$ (Pareja et al. 2013). Over the CPB, the Colombian Current (CoC) flows to the north next to Colombia's coast (Wooster 1959). When CoC is weak, it forms the eastern limb (Rodríguez-Rubio et al. 2003), called Panama Bight Cyclonic Gyre (PBCG). In the south sector of the $\mathrm{CPB}$, the North Equatorial
Countercurrent (NECC) flows southeastward (Kessler 2006), almost reaching the coast of Colombia (Villegas $\&$ Malikov 2006). The South Equatorial Current (SEC) originated as a combination of equatorial upwelling, mixing, and advection from the NECC and Peru coastal upwelling (Kessler 2006) carries cold waters to the southwest sector of the CPB (Villegas \& Malikov 2006).

The schematic drawing of the sectors in which the study regions are divided based on its surface thermohaline characteristics' homogeneity is shown (Fig. 3). The sectors in Figure 3a were defined by Rodriguez et al. (2010) from a spatial and temporal analysis of multiyear (1971-2000) surface atmospheric (Ta and relative humidity, $\mathrm{RH}$ ) and oceanic (sea surface temperature, SST and sea surface salinity, SSS) data for the CCS. The sectors in Figure $3 \mathrm{~b}$ are the result of cluster analysis of multiyear (1971-2000) SST, SSS, and sea surface density anomaly (SSDA) data carried out by Villegas \& Malikov (2009) for the CPB. Figure 3a shows on the left the Caribbean Warm Pool (CWP), the Caribbean Cold Pool (CCP), and the La Guajira Upwelling system (LGU), sectors which are mentioned and studied in Ruiz-Ochoa et al. (2012), Rueda-Roa \& Muller-Karger (2013), Andrade (2015), and others. The homogeneous zones for $\mathrm{CPB}$, which are shown in Figure $3 \mathrm{~b}$ on the right, are known as Cold Coastal Surface Water (CCSW), Warm Coastal Surface Water 

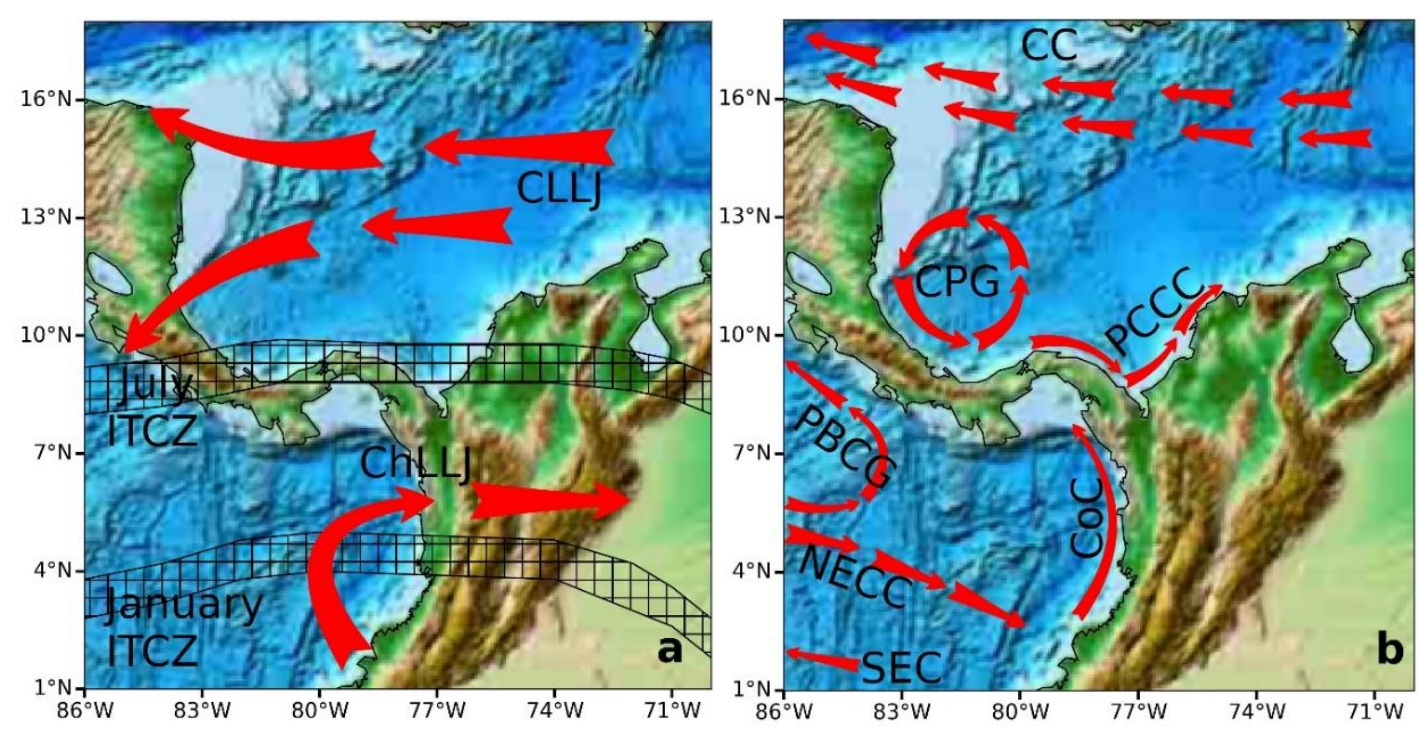

Figure 2. Schematic drawing of a) atmospheric features and b) currents over the Colombian Caribbean Sea and the Colombian Pacific Basin. ITCZ: Intertropical Convergence Zone, CLLJ: Caribbean Low-Level Jet, ChLLJ: Choco LowLevel Jet, CC: Caribbean Current, CPG: Colombia-Panama Gyre, PCCC: Panama Colombia Counter Current, CoC: Colombian Current, PBCG: Panama Bight Cyclonic Gyre, NECC: North Equatorial Countercurrent, SEC: South Equatorial Current.

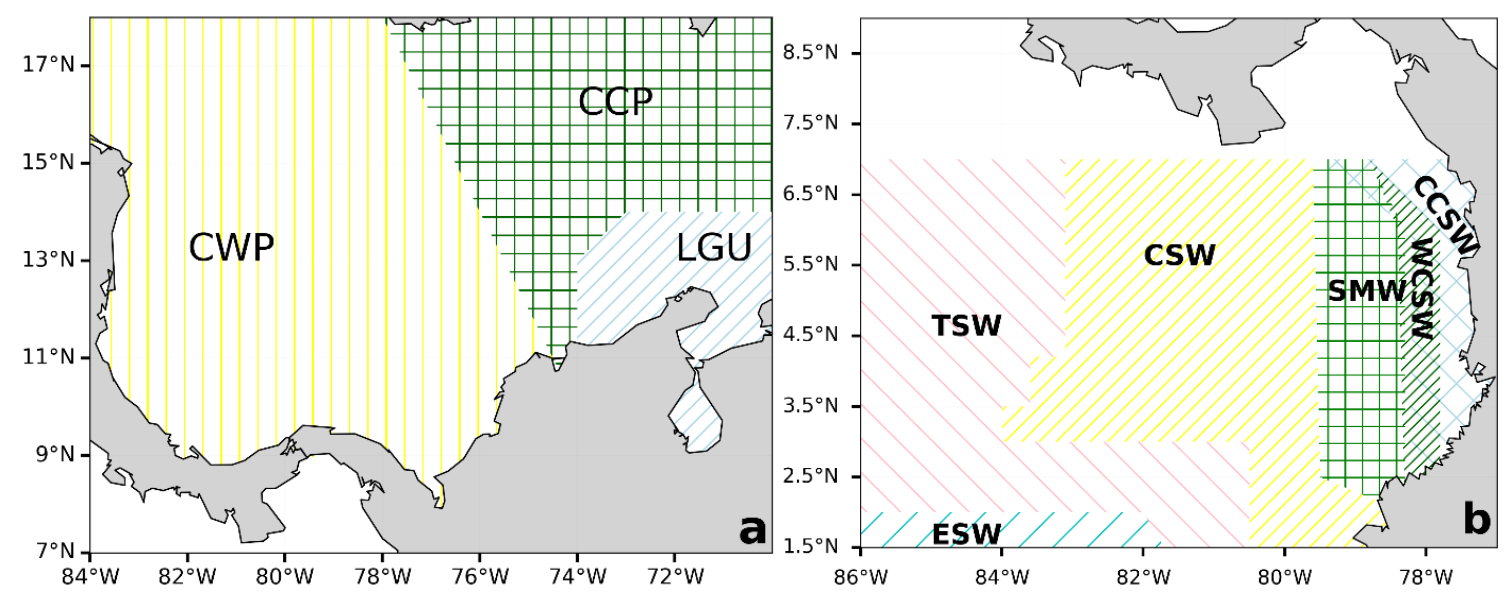

Figure 3. Schematic drawing of homogeneous zones over the study areas. a) Colombian Caribbean Sea. CWP: Caribbean Warm Pool, CCP: Caribbean Cold Pool, LGU: La Guajira Upwelling, b) Colombian Pacific Basin. CCSW: Cold Coastal Surface Water, WCSW: Warm Coastal Surface Water, SMW: Surface Mixing Water, CSW: Colombian Surface Water, TSW: Tropical Surface Water, ESW: Equatorial Surface Water.

(WCSW), Surface Mixing Water (SMW), Colombian Surface Water (CSW), Tropical Surface Water (TSW), and Equatorial Surface Water (ESW). These have been the basis for studies in Malikov et al. (2010), Malikov \& Villegas (2010), Díaz et al. (2011), Navia et al. (2015), and others.

Numerous authors have written about the evidence of global warming in atmospheric and hydroclimatic characteristics of the continental area of Colombia, but very few mention Colombia's maritime regions. It is also only fair to say that, because research on global warming requires long-term time series, it is necessary to have both real and simulated information over these regions. The use of numerical models makes it possible to simulate projections over several years, visualizing both trends and possible global warming effects. In order to include the effect of anthropogenic factors in the simulations, the IPCC (2014) proposed representing global annual emissions of greenhouse gases (GHG) in equivalent carbon dioxide terms called Representative 
Concentration Pathways (RCPs). Considering different RCPs $\left(2.6,4.5,6.0\right.$ and $\left.8.5 \mathrm{~W} \mathrm{~m}^{-2}\right)$, it is possible to compare observed data with simulated information and understand changes in oscillations and regimes in the past and future climate variables. Given the importance of increasing our knowledge about climate change and climate variability in Colombia, the present article seeks to show the SST representation and its trend to 2035 identified from the numerical experiment conducted with the Regional Ocean Modeling System (ROMS) considering RCP4.5. Since this is a global warming scenario that might well be perceived in the coming years (IPCC 2014), information relating to SST trends could be useful to the country in the not too distant future and represent the basis for contingency plans aimed at promptly alerting at-risk populations, mitigating adverse effects, and adapting to new conditions.

\section{MATERIALS AND METHODS}

The study regions are in the northern part of the South American continent. CCS is located between $7^{\circ} 00^{\prime}-$ $18^{\circ} 00^{\prime} \mathrm{N}$ and $70^{\circ} 00^{\prime}-84^{\circ} 00^{\prime} \mathrm{W}$ and the $\mathrm{CPB}$ between $1^{\circ} 30^{\prime}-9^{\circ} 00^{\prime} \mathrm{N}$ and $77^{\circ} 40^{\prime}-86^{\circ} 00^{\prime} \mathrm{W}$. Figure 1 presents the selected geographical points (stations), from which we analyze the SST of nearby waters. These stations were selected because of their location in coastal sectors vulnerable to global warming, either due to their proximity to human settlements or natural parks (DNP 2012). Therefore, the results and SST trends are shown for waters situated near Colombia's important geographic sectors. The stations selected for CCS and its coordinates are: Punta Gallinas (PG: $71^{\circ} 40^{\prime} 00^{\prime \prime} \mathrm{W}-$ $12^{\circ} 27^{\prime} 28^{\prime \prime N}$ ), Portete Bay (PB: $\left.72^{\circ} 00^{\prime} 21^{\prime \prime} \mathrm{W}-12^{\circ} 16^{\prime} 48^{\prime \prime} \mathrm{N}\right)$, Tayrona Park (TP: $\left.74^{\circ} 11^{\prime} 00^{\prime \prime} \mathrm{W}-11^{\circ} 18^{\prime} 00^{\prime \prime N}\right)$, Rosario Island (RI: $75^{\circ} 45^{\prime} 00^{\prime \prime} \mathrm{W}-10^{\circ} 10^{\prime} 30^{\prime \prime} \mathrm{N}$ ) and Providencia Island (PI: $81^{\circ} 22^{\prime} 29^{\prime \prime} \mathrm{W}, 3^{\circ} 20^{\prime} 56^{\prime \prime} \mathrm{N}$ ). The stations selected for CPB and its coordinates are: Solano Bay (SB: $77^{\circ} 24^{\prime} 14^{\prime \prime} \mathrm{W}, 06^{\circ} 13^{\prime} 27^{\prime \prime} \mathrm{N}$ ), Buenaventura Port (BP: 77 $01^{\prime} 36^{\prime \prime} \mathrm{W}, \quad 03^{\circ} 52^{\prime} 38^{\prime \prime} \mathrm{N}$ ), Gorgona Island (GI: $78^{\circ} 10^{\prime} 00^{\prime \prime} \mathrm{W}, \quad 02^{\circ} 58^{\prime} 00^{\prime \prime} \mathrm{N}$ ), Tumaco Port (TPo: $78^{\circ} 45^{\prime} 53^{\prime \prime} \mathrm{W}, 01^{\circ} 48^{\prime} 24 " \mathrm{~N}$ ), and Malpelo Island (MI: $81^{\circ} 35^{\prime} 29^{\prime \prime} \mathrm{W}, 03^{\circ} 58^{\prime} 36^{\prime \prime N}$ ) (Fig. 1).

\section{Sea surface temperature (SST) simulation}

The modeled SST comes from the thermohaline and dynamic simulation of the Colombian marine regions performed with ROMS, an ocean circulation model designed to simulate regional systems dynamics in a numerical code developed by Rutgers University. The model solves the primitive equations of the system in rotation with a free surface, potential temperature, salinity, and the equation of state, based on the
Boussinesq approximation and the hydrostatic vertical momentum balance satisfying the 3D continuity equation for an incompressible fluid (Shchepetkin \& McWilliams 2009). We have carried out four independent simulations: two for the CCS and another two for the CPB, both for the 1970-2007 and 2008-2035 periods. The domains of each simulation are seen in Figure 1. The CCS domain is a $1554 \mathrm{~km}$ longitude by $1221 \mathrm{~km}$ latitude with a spatial resolution of $10 \mathrm{~km}$ $\left(\sim 0.1^{\circ}\right)$, and for CPB is a $955 \mathrm{~km}$ longitude by $833 \mathrm{~km}$ latitude with a resolution of $12 \mathrm{~km}\left(\sim 0.11^{\circ}\right)$. The number of grid points in the horizontal plane is $155 \times 122$ for the CCS and $80 \times 69$ for the CPB. In the vertical, both domains have 24 terrain-following levels using the s-coordinate system. The simulations were performed with a temporal resolution of 1000 and 900 seconds for CSC and CPB respectively.

At the open boundaries (north, east in the CCS, and south, west in the CPB), a combination of outward advection and radiation and flow adaptive nudging toward prescribed external conditions (Marchesiello et al. 2001) was used. This approach allows the long-term stable integration of regional ocean models. The external conditions are the monthly mean data provided from the Modular Ocean Model (MOM4.1) for the 1970-2007 simulation period and the Max Planck Institute (MPI) Ocean Model (MPIOM) for the 20082035 period run with RCP4.5. Non-slip condition is applied at the coastal boundaries. A quadratic drag is applied to the bottom friction with a drag coefficient of 0.0026 . Harmonic horizontal mixing along isopycnal surfaces is applied to the tracers, and biharmonic horizontal mixing along constant sigma surfaces is applied to the momentum. Advection of momentum uses the upwind third-order scheme in the horizontal and the centered fourth-order scheme in the vertical (Shchepetkin \& McWilliams 2005). K-profile turbulence closure (Large et al. 1994) is used for vertical mixing.

Initial salinity and temperature for the reference period 1970-2007 are set as the climatology from the World Ocean Atlas 2013 version 2 (WOA13v2, Locarnini et al. 2013, Zweng et al. 2013) and the velocity and sea surface height fields from the MOM4.1 $\left(0.25 \times 0.25^{\circ}\right.$ horizontal resolution), after its interpolation onto the model grid. The initial conditions for the 2008-2035 period are the climatological values derived from the MPIOM $\left(0.45 \times 0.42^{\circ}\right.$ horizontal resolution) performed for the RCP4.5, after interpolating temperature, salinity, velocities, and sea surface height fields onto the model grid. At the surface, the historical run is forced with six-hourly atmospheric fields from the Reanalysis NCEP/NCAR, which horizontal resolution is $\sim 1.875 \times 1.875^{\circ}$ (Kalnay et al. 1996 , Kistler et al. 
2001). The future run (2008-2035 period) is forced with atmospheric fields from the regional climate model RegCM4.1 $\left(0.45 \times 0.42^{\circ}\right.$ horizontal resolution $)$ performed with the RCP4.5 (Giorgi et al. 2012). Surface heat and momentum fluxes are determined through the ROMS bulk-flux option. For both simulation periods (1970-2007 and 2008-2035) constant river flows were incorporated (Atrato, Magdalena, Sinú for CCS and San Juan, Patía, Mira rivers for $\mathrm{CPB}$ ), which were obtained from the Colombian Instituto de Hidrología, Meteorología y Estudios Ambientales (IDEAM 2016). The bathymetry was extracted from ETOPO2 (Smith \& Sandwell 1997). The model grid, forcing, initial and boundary conditions were built using the ROMSTOOLS package developed by the Institut de Recherche pour le Développement (IRD) (Penven et al. 2008).

According to the analysis carried out in Villegas et al. (2013), it was concluded that the information most suitable to be used as boundary conditions for the simulation of CCS and CPB is the thermohaline and dynamic monthly fields resulting from MOM4.1. The MOM4.1 model reproduces global ocean information through the numerical representation of the primitive hydrostatic equations, and it has been mainly designed as a tool for studying the ocean climate system, but it is also used in regional and coastal applications (Griffies 2009).

For the 2008-2035 period, we required oceanic and atmospheric results of models to visualize a mediumterm future represented in scenario RCP4.5. Therefore, we used as initial and boundary conditions the thermohaline and dynamic fields obtained from the MPIOM (Marsland et al. 2003), and for the atmospheric forcing, we used the results from the regional climate model RegCM4.1, taking into consideration the RCP4.5. The MPIOM is an ocean Global Circulation Model (GCM) that is part of the MPI Earth System Model (MPI-ESM) based on primitive equations with the representation of thermodynamic processes capable of simulating the oceanic circulation from small scales to gyre scales in response to atmospheric forcing fields (Wetzel et al. 2010). The MPIOM has been forced with the atmospheric GCM developed by the MPI from the sixth generation European Center Hamburg Model (ECHAM6), which is also part of the MPI-ESM (Roeckner et al. 2003, Jungclaus et al. 2013, Stevens et al. 2013), known as ECHAM6/MPIOM. RegCM4.1 is a hydrostatic version of the Mesoscale Model version 5 (MM5) of the State University of Pennsylvania, which was developed and run by the International Center for Theoretical Physics (ICTP) under the Coordinated Regional Downscaling Experiment (CORDEX, Giorgi et al. 2012), where our two study regions are located.
The configuration, as indicated in Fuentes-Franco et al. (2015), includes an enhanced version of the radiativetransfer scheme (Kiehl et al. 1996), the resolvable precipitation scheme (Pal et al. 2000), Emanuel's convection scheme (Emanuel 1991) together with the Community Land Model (CLM) version 3.5 land surface scheme (Oleson et al. 2008), driven by the Hadley Center Global Environment Model (HadGEM).

Daily results of SL and 24 depth ocean levels of U$\mathrm{V}$ components, temperature, and salinity were obtained for the 1970-2007 and 2008-2035 periods. From these results, the present document shows the modeled SST. The reference period is compared spatially with observational data detecting sectors with bias. For geographic points selected because of their importance to Colombia, located in waters near continental and insular coasts, deviation measures are shown comparing SST time series. Both spatially and temporally, we show SST trends for the 1970-2007 and 2008-2035 periods.

\section{Deviation measurements and trends}

The spatial comparison using ICOADS (Slutz et al. 1985), OSTIA (Donlon et al. 2012), and SST ROMS data was carried out even though there is a difference in the spatial resolution between them. While the ICOADS spatial resolution is $1 \times 1^{\circ}$ and OSTIA $1 / 20^{\circ}$ $(\sim 6 \times 6 \mathrm{~km})$, the results in ROMS have a spatial resolution of $10 \mathrm{~km}\left(\sim 0.1^{\circ}\right)$ for the CCS and $12 \mathrm{~km}$ $\left(\sim 0.11^{\circ}\right)$ for the CPB. Therefore, we had performed an interpolation with the Kriging method (Paulson \& Ragkousis 2015), allowing the comparison between ICOADS, OSTIA, and SST ROMS data. Since OSTIA data is available from 1982, the bias between ROMS results, ICOADS, and OSTIA data was obtained from the multiyear SST average for the period 1982-2007:

$$
\mathrm{BIAS}=\frac{1}{n} \sum_{\mathrm{i}=1}^{n} M_{i}-\frac{1}{n} \sum_{\mathrm{i}=1}^{n} O_{i}=\bar{M}_{i} \bar{O}_{i},
$$

where $M_{i}$ is the $i$-th modeled value and $O_{i}$ is the $i$-th observed value.

We extracted from ICOADS and OSTIA the SST information closest to the coordinates of the geographic points of interest. In order to make up for missing data in the time series, the corresponding base climatology's were calculated with which values were replaced in 1961-1990 and 1981-2010 reference periods, a suggestion first put forward and explained in Xue et al. (2003) and Lindsey (2013). The average, minimum, and maximum values and the SST amplitude of the resulting series from ROMS were compared with the SST series from ICOADS and OSTIA for the insular and continental coastal stations selected in both regions for the 1982-2007 period. Also, for these stations, the 
comparison took place in a longer time series (19702007 period) with ICOADS, calculating model deviation measures, such as model efficiency:

$$
\mathrm{ME}=1-\frac{\sum_{i=1}^{n}\left(O_{i}-M_{i}\right)^{2}}{\sum_{i=1}^{n}\left(o_{i}-\bar{O}\right)^{2}},
$$

where $\bar{O}$ is the arithmetic mean of observed values;

coefficient of model determination $\quad \mathrm{CMD}=\frac{\sum_{i=1}^{n}\left(o_{i}-\bar{O}\right)^{2}}{\sum_{i=1}^{n}\left(M_{i}-\bar{O}\right)^{2}}$

mean absolute error

MAE $=\frac{1}{n} \sum_{\mathrm{i}=1}^{n}\left|O_{i}-M_{i}\right|$

and error coefficient

$$
\mathrm{EC}=\frac{\left(\frac{\sum_{i=1}^{n}\left|o_{i}-M_{i}\right|}{n}\right)}{\bar{o}}
$$

Several authors (Willmot et al. 1985, Legates \& Mccabe 1999, Tedeschi 2006) have successfully used these metrics to compare modeled and observed time series in fields such as hydrometeorology and climatology, and an exhaustive explanation of the usefulness of these metrics can be found in JWGFVR (2009), Wilks (2011), and Jolliffe \& Stephenson (2012).

To visualize SST trends in the recent past and to 2035, the multi-annual linear regression estimated in both regions (significant for $95 \%$ confidence level) was spatially plotted. The multi-annual time series from the simulation were plotted overlapping with the ICOADS multiyear time series for the selected insular and continental coast stations, each with their respective trends.

\section{RESULTS}

\section{Comparing results and identifying trends}

The spatial bias calculated for the 1982-2007 period in the CCS between the simulated ROMS and ICOADS data is shown in Figure 4a and those between ROMS and OSTIA in Figure 4b. The dotted lines in Figure 4 correspond to the isocontours: $-1^{\circ} \mathrm{C}$ (white), $-0.05^{\circ} \mathrm{C}$ (blue), $0^{\circ} \mathrm{C}$ (black), $0.05^{\circ} \mathrm{C}$ (red) and $1^{\circ} \mathrm{C}$ (silver). Solid lines correspond to the color bar, which limits are minimum $-1.8^{\circ} \mathrm{C}$, maximum $1.7^{\circ} \mathrm{C}$, and the contour interval is $0.05^{\circ} \mathrm{C}$. The minimum bias with ICOADS is $-1.2^{\circ} \mathrm{C}$, located in the northeast of the $\mathrm{CCS}$ at $73^{\circ} \mathrm{W}$. The maximum bias with ICOADS is $0.52^{\circ} \mathrm{C}$, located on the Panamanian coast around $78^{\circ} \mathrm{W}$. The biases with OSTIA vary between $-1.8^{\circ} \mathrm{C}$ in Maracaibo Lake and $0.4^{\circ} \mathrm{C}$ in the southeast of the study region. Positive values show that ROMS simulated a higher SST than those registered by ICOADS and OSTIA data, especially in sectors close to the Panamanian coast between $79^{\circ} \mathrm{W}$ and $8-10^{\circ} \mathrm{N}$. High biases also emerge in a sector where there is a permanently low SST, calculated with the high-resolution OSTIA satellite database, in the well-known LGU. Other positive biases with OSTIA data in Figure 4b mark a large area that crosses the study region parallel to the Colombian Caribbean coast between latitudes 15 and $18^{\circ} \mathrm{N}$.

In contrast, the biases presented by ICOADS in this sector are negative, and they extend in the CCS central part. Negative biases show that ROMS calculated lower values than those registered by ICOADS in that area. The region located beyond $81^{\circ} \mathrm{W}$ (Fig. $4 \mathrm{a}$ ) between 11 and $15^{\circ} \mathrm{N}$ coincides with the sector of negative biases situated beyond $80^{\circ} \mathrm{W}$ (Fig. $4 \mathrm{~b}$ ) in the same latitudes.

SST results obtained with ROMS for CPB are better than those obtained for CCS, which are revealed by lower spatial bias values than the latter (Fig. 5). The dotted lines, color bar limits, and intervals in Figure 5 are the same as in Figure 4. The CPB bias calculated with ICOADS data (Fig. 5a) presents values between $0.6^{\circ} \mathrm{C}$ in the Colombian Pacific coast at $3^{\circ} \mathrm{N}$ and $0.1^{\circ} \mathrm{C}$ at $80^{\circ} 30^{\prime} \mathrm{W}-5^{\circ} \mathrm{N}$. Biases calculated with OSTIA data (Fig. 5b) vary between $-0.75^{\circ} \mathrm{C}$ located simultaneously in ICOADS biases and $0.25^{\circ} \mathrm{C}$ at $80^{\circ} \mathrm{W}-6^{\circ} \mathrm{N}$. High positive bias shows the overestimation of SST in the ROMS results (Fig. 5a, bias with ICOADS), highlighted close to the limit between CSW and SMW, where the mixing surface water occurs, around the longitudes $80^{\circ} 30^{\prime}-81^{\circ} 30^{\prime} \mathrm{W}$ and the latitude $5^{\circ} \mathrm{N}$. Another high positive bias is shown in the sector between $5.5-7.5^{\circ} \mathrm{N}$ and $85^{\circ} \mathrm{W}$. In Figure $5 \mathrm{~b}$ (bias with OSTIA), these areas expand their dimensions, especially the first one, which continues towards the Panama coast. Negative biases are found practically throughout the region (Figs. 5a-b). The lowest is found in coastal sectors where the Mira, Patía, and San Juan rivers' mouths are found and towards the Chocó coast between $5^{\circ} 30^{\prime}-6^{\circ} 30^{\prime} \mathrm{N}$. Figure 5a remarks the negative bias also presented in Figure 5b in the southwest sector.

Comparing SST characteristics as mean, minimum, maximum, and amplitude between ICOADS, ROMS, and OSTIA series 1982-2007 (Table 1), it can be seen that the series are quite similar to each other. The SST series simulated by ROMS showed less variability, obtaining lower SST amplitudes than the ICOADS and OSTIA. This was expected because the ROMS results represent the response to global and regional forcing, but not to local ones, so modeled SST series are more smoothed than observed SST series.

Table 2 presents the deviation measures between the 1970-2007 period SST series simulated with ROMS and those of ICOADS, obtained from waters closest to the coastal and insular geographic points of interest for Colombia. According to Medina-Peralta et al. (2010), when $\mathrm{ME}=1$, it can be said that the model fits the data well. Table 1 shows that the ME deviation measurement presented a good fit between the simulated SST 

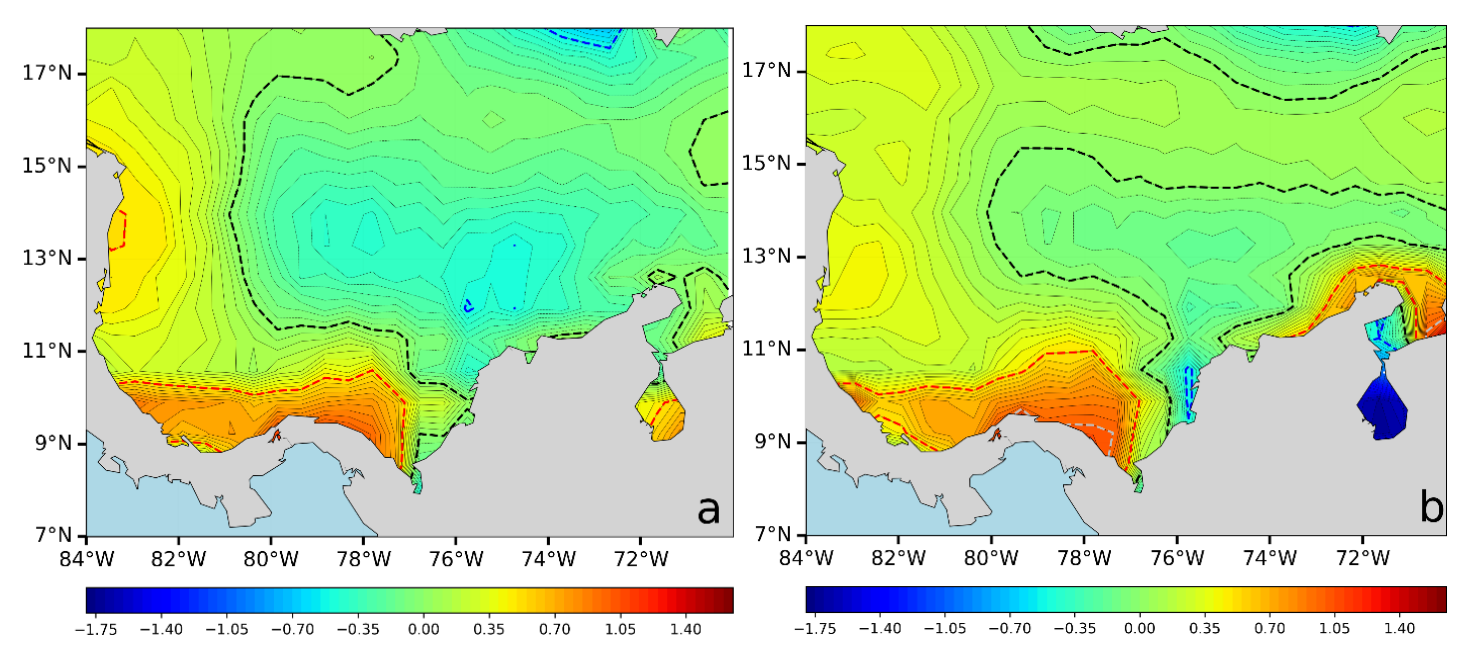

Figure 4. Colombian Caribbean Sea. Bias for the 1982-2007 period between SST $\left({ }^{\circ} \mathrm{C}\right)$ simulated with Regional Ocean Modeling System (ROMS) and SST $\left({ }^{\circ} \mathrm{C}\right)$ data from a) International Comprehensive Ocean-Atmosphere Data Sets (ICOADS) and b) Operational Sea Surface Temperature and Sea Ice Analysis (OSTIA). Color bar limits: min. $-1.8^{\circ} \mathrm{C}$, max. $1.7^{\circ} \mathrm{C}$. Contour interval $0.05^{\circ} \mathrm{C}$. Dotted lines are white $-1^{\circ} \mathrm{C}$, blue $-0.05^{\circ} \mathrm{C}$, black $0^{\circ} \mathrm{C}$, red $0.05^{\circ} \mathrm{C}$, and silver $1^{\circ} \mathrm{C}$.
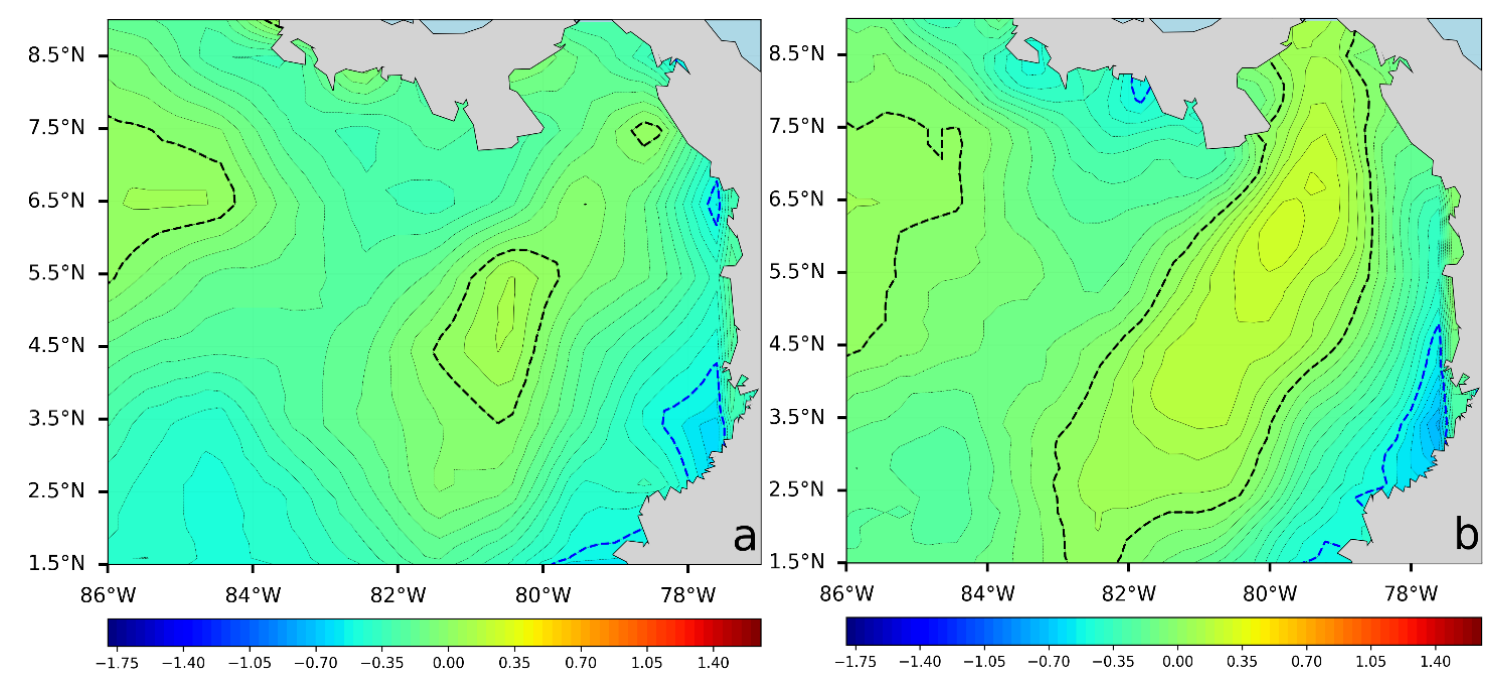

Figure 5. Colombian Pacific Basin. Bias for the 1982-2007 period between SST $\left({ }^{\circ} \mathrm{C}\right)$ simulated with Regional Ocean Modeling System (ROMS) and SST $\left({ }^{\circ} \mathrm{C}\right)$ data from a) International Comprehensive Ocean-Atmosphere Data Sets (ICOADS) and b) Operational Sea Surface Temperature and Sea Ice Analysis (OSTIA). Color bar limits: min. $-1.8^{\circ} \mathrm{C}$, max. $1.7^{\circ} \mathrm{C}$. Contour interval $0.05^{\circ} \mathrm{C}$. Dotted lines are white $-1^{\circ} \mathrm{C}$, blue $-0.05^{\circ} \mathrm{C}$, black $0^{\circ} \mathrm{C}$, red $0.05^{\circ} \mathrm{C}$, and silver $1^{\circ} \mathrm{C}$.

with ROMS and the ICOADS SST for all selected stations with values greater than 0.81 , except for PI and $\mathrm{PB}$, which presented values 0.7 and 0.68 , respectively. The proportion of the total variance of the observed values explained by the modeled data can be obtained with the CMD measure (Loague \& Green 1991), which states that the closer it is to 1 , the better are the results provided by the model, if CMD $>1$ is an indicator of underestimation and if CMD $<1$ of overestimation. In this case, RI presented the best results, together with GI, with a CMD equal to 1 , but overestimated stations such as PB and PG stand out.
MAE represents the average absolute difference between observed and modeled values, meaning that the closer it is to zero, the less error the modeled data present concerning the observed ones (Mayer \& Butler 1993). PB stands out for having the highest MAE between the two regions series, while the others present values around 0.1 , showing that the ROMS results are acceptable (Table 2). The fit of the model to the observed data is also described with EC, a relatively average measure of the absolute differences between observed and modeled values expressed as the proportion of the observed values mean (Medina- 
Table 1. Sea surface temperature (SST, ${ }^{\circ} \mathrm{C}$ ) mean, minimum (Min.), maximum (Max.), and amplitude in International Comprehensive Ocean-Atmosphere Data Sets (ICOADS), Regional Ocean Modeling System (ROMS), and Operational Sea Surface Temperature and Sea Ice Analysis (OSTIA) series 1982-2007 at insular and continental coastal stations of Colombian Caribbean Sea and Colombian Pacific Basin. PG: Punta Gallinas, PB: Portete Bay, TP: Tayrona Park, RI: Rosario Island, PI: Providencia Island, SB: Solano Bay, BP: Buenaventura Port, GI: Gorgona Island, TPo: Tumaco Port, MI: Malpelo Island.

\begin{tabular}{|c|c|c|c|c|c|c|c|c|c|c|c|}
\hline \multirow{2}{*}{\multicolumn{2}{|c|}{ Series / Basic statistics }} & \multicolumn{5}{|c|}{ Colombian Caribbean Sea } & \multicolumn{5}{|c|}{ Colombian Pacific Basin } \\
\hline & & PG & $\mathrm{PB}$ & TP & RI & PI & SB & $\mathrm{BP}$ & GI & TPo & MI \\
\hline \multirow{4}{*}{ ICOADS SST $\left({ }^{\circ} \mathrm{C}\right)$} & Mean & 26.96 & 27.03 & 27.55 & 27.55 & 27.85 & 27.4 & 27.26 & 27.02 & 26.98 & 27.15 \\
\hline & Min. & 26.32 & 26.43 & 26.91 & 27.23 & 27.04 & 26.47 & 26.2 & 26.41 & 26.26 & 26.29 \\
\hline & Max. & 27.95 & 28.22 & 28.33 & 28.53 & 28.66 & 28.6 & 28.15 & 27.92 & 28.08 & 28.45 \\
\hline & Amplitude & 1.63 & 1.79 & 1.42 & 1.30 & 1.62 & 2.13 & 1.95 & 1.51 & 1.82 & 2.16 \\
\hline \multirow{4}{*}{ ROMS SST $\left({ }^{\circ} \mathrm{C}\right)$} & Mean & 26.92 & 26.97 & 27.45 & 27.85 & 27.95 & 27.4 & 27.3 & 27.06 & 26.97 & 27.09 \\
\hline & Min. & 26.37 & 26.27 & 26.95 & 27.23 & 27.1 & 26.66 & 26.56 & 26.45 & 26.26 & 26.46 \\
\hline & Max. & 27.75 & 27.76 & 28.14 & 28.43 & 28.7 & 28.44 & 28.15 & 27.99 & 27.91 & 28.19 \\
\hline & Amplitude & 1.38 & 1.49 & 1.19 & 1.20 & 1.60 & 1.78 & 1.59 & 1.54 & 1.65 & 1.73 \\
\hline \multirow{4}{*}{ OSTIA SST $\left({ }^{\circ} \mathrm{C}\right)$} & Mean & 26.29 & 26.12 & 27.25 & 28.56 & 27.87 & 27.6 & 27.69 & 27.36 & 27.03 & 26.99 \\
\hline & Min. & 25.68 & 25.51 & 26.81 & 27.98 & 27.37 & 26.78 & 26.89 & 26.64 & 26.44 & 26.4 \\
\hline & Max. & 27.2 & 27.06 & 27.96 & 29.21 & 28.46 & 28.7 & 28.95 & 28.47 & 27.97 & 28.27 \\
\hline & Amplitude & 1.52 & 1.55 & 1.15 & 1.23 & 1.09 & 1.92 & 2.06 & 1.83 & 1.53 & 1.87 \\
\hline
\end{tabular}

Table 2. Deviation measures of sea surface temperature $\left(\mathrm{SST},{ }^{\circ} \mathrm{C}\right)$ between Regional Ocean Modeling System (ROMS) and International Comprehensive Ocean-Atmosphere Data Sets (ICOADS) at insular and continental coastal stations of the Colombian Caribbean Sea and Colombian Pacific Basin for the 1970-2007 period. PG: Punta Gallinas, PB: Portete Bay, TP: Tayrona Park, RI: Rosario Island, PI: Providencia Island, SB: Solano Bay, BP: Buenaventura Port, GI: Gorgona Island, TPo: Tumaco Port, MI: Malpelo Island, ME: model efficiency, CMD: coefficient of model determination, MAE: mean absolute error, EC: error coefficient.

\begin{tabular}{|c|c|c|c|c|c|c|c|c|c|c|}
\hline \multirow{2}{*}{ Deviation measures } & \multicolumn{5}{|c|}{ Colombian Caribbean Sea } & \multicolumn{5}{|c|}{ Colombian Pacific Basin } \\
\hline & PG & $\mathrm{PB}$ & $\mathrm{TP}$ & RI & PI & SB & BP & GI & TPo & MI \\
\hline $\mathrm{ME}$ & 0.82 & 0.68 & 0.81 & 0.85 & 0.7 & 0.85 & 0.88 & 0.81 & 0.85 & 0.88 \\
\hline CMD & 1.6 & 1.7 & 1.5 & 1.0 & 0.9 & 1.1 & 1.1 & 1.0 & 1.2 & 1.3 \\
\hline $\operatorname{MAE}\left({ }^{\circ} \mathrm{C}\right)$ & 0.14 & 0.20 & 0.15 & 0.11 & 0.14 & 0.14 & 0.11 & 0.12 & 0.15 & 0.15 \\
\hline $\mathrm{EC}$ & 0.005 & 0.008 & 0.005 & 0.004 & 0.005 & 0.005 & 0.004 & 0.005 & 0.006 & 0.006 \\
\hline
\end{tabular}

Peralta et al. 2010). Therefore, the model is better adjusted to the observed data if EC is close to 0 , which was appreciated in the selected insular and continental coast stations, obtaining a higher EC in PB.

\section{SST trends}

The linear multi-annual SST trend for the 1970-2007 period with ICOADS data in the CCS and CPB is shown (Figs. 6a and 6b, respectively). The dotted lines in Figure 6 correspond to the isocontours: $0^{\circ} \mathrm{C} \mathrm{yr}^{-1}$ (white), $0.01^{\circ} \mathrm{C}^{-1}$ (blue), $0.02^{\circ} \mathrm{C}^{-1}$ (brown) and $0.03^{\circ} \mathrm{C} \mathrm{yr}^{-1}$ (red). Solid lines correspond to the color bar which limits are min. $0.01^{\circ} \mathrm{C} \mathrm{yr}^{-1}$, max. $0.04^{\circ} \mathrm{C} \mathrm{yr}^{-1}$, and the contour interval is $0.0015^{\circ} \mathrm{C} \mathrm{yr}^{-1}$. The positive trend practically covers both regions, and the negative trend is confined to specific sectors. In CCS, the minimum negative multi-annual linear trend for 1970-2007 $\left(-0.09^{\circ} \mathrm{C} \mathrm{yr}^{-1}\right)$ is situated west on the Central American coast, between $12-15^{\circ} \mathrm{N}$ and $81-83^{\circ} \mathrm{W}$, and also observed in a small sector between $16^{\circ} 30^{\prime} \mathrm{N}$ and $73^{\circ} 30^{\prime} \mathrm{W}$. The maximum positive trend $\left(0.035^{\circ} \mathrm{C} \mathrm{yr}^{-1}\right)$ is found on the Panamanian coast at $77^{\circ} 30^{\prime} \mathrm{W}$ (Fig. 6a). The minimum negative multi-annual linear trend for 1970-2007 in the CPB $\left(-0.003^{\circ} \mathrm{C}^{-1}\right)$ is located on the north of the Colombian Pacific coast at $6-7^{\circ} \mathrm{N}$ and the maximum positive trend $\left(0.033^{\circ} \mathrm{C} \mathrm{yr}^{-1}\right)$ at $4^{\circ} 30^{\prime} \mathrm{N}$ and $85^{\circ} 30^{\prime} \mathrm{W}$ (Fig. 6b). Low positive trends $\left(0.01^{\circ} \mathrm{C} \mathrm{yr}^{-1}\right)$ are found in Central American pacific coast between $8^{\circ} \mathrm{N}$ and $82^{\circ} \mathrm{W}$ and in Colombian Pacific coast at $1^{\circ} 30^{\prime}$ and $5^{\circ} \mathrm{N}$.

Figures 7a,b show the linear multi-annual SST trend for the 2008-2035 period with ROMS data in the CCS and $\mathrm{CPB}$, respectively, with dotted lines, solid lines, color bar limits, and contour interval as in Figure 6. Waters around the coast of Central America (Fig. 7a) present a positive trend $\left(\sim 0.016^{\circ} \mathrm{C} \mathrm{yr}^{-1}\right)$ showing a 

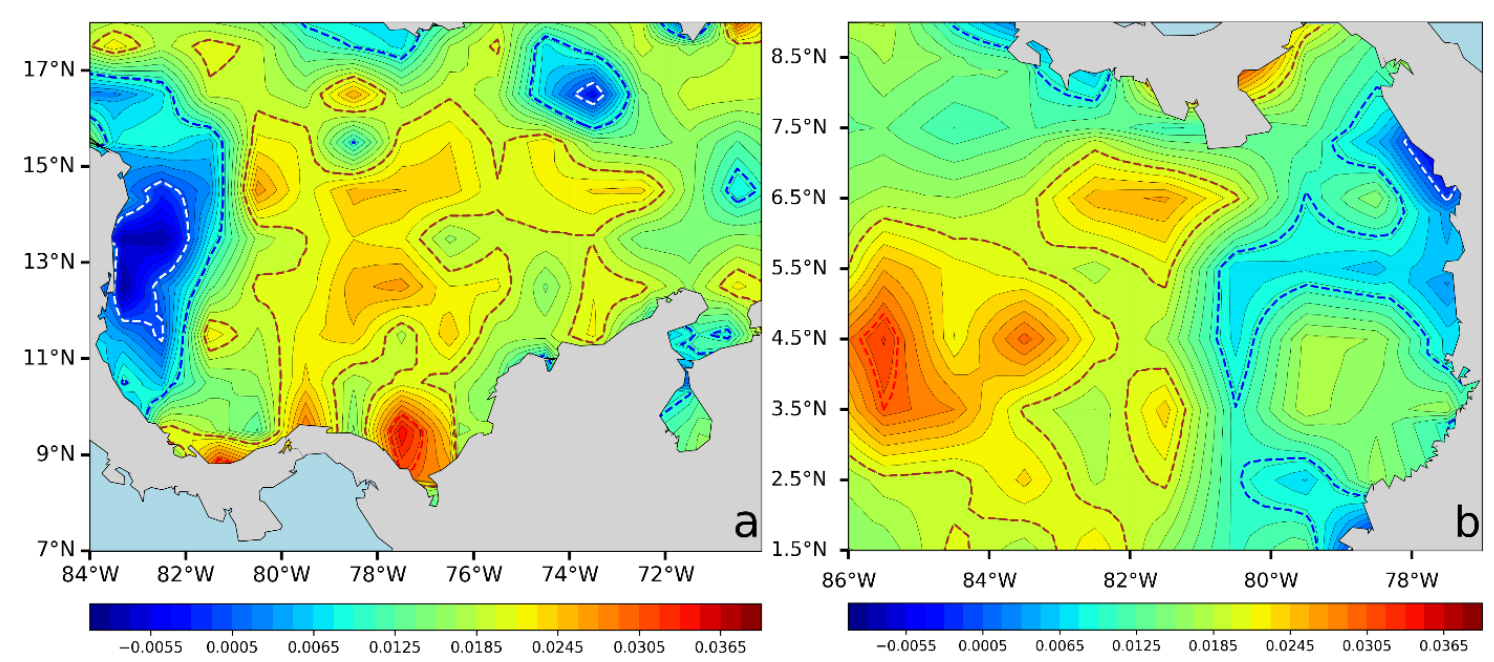

Figure 6. The multi-annual linear trend of sea surface temperature $\left({ }^{\circ} \mathrm{C} \mathrm{yr}^{-1}\right)$ from International Comprehensive OceanAtmosphere Data Sets (ICOADS) 1970-2007 period. Significant for 95\% confidence level. a) Colombian Caribbean Sea, b) Colombian Pacific Basin. Color bar limits: min. $-0.01^{\circ} \mathrm{C} \mathrm{yr}^{-1}$, max. $0.04^{\circ} \mathrm{C} \mathrm{yr}^{-1}$. Contour interval $0.0015^{\circ} \mathrm{C} \mathrm{yr}^{-1}$. Dotted lines are: white $0^{\circ} \mathrm{C} \mathrm{yr}^{-1}$, blue $0.01^{\circ} \mathrm{C} \mathrm{yr}^{-1}$, brown $0.02^{\circ} \mathrm{C} \mathrm{yr}^{-1}$, red $0.03^{\circ} \mathrm{C} \mathrm{yr}^{-1}$.

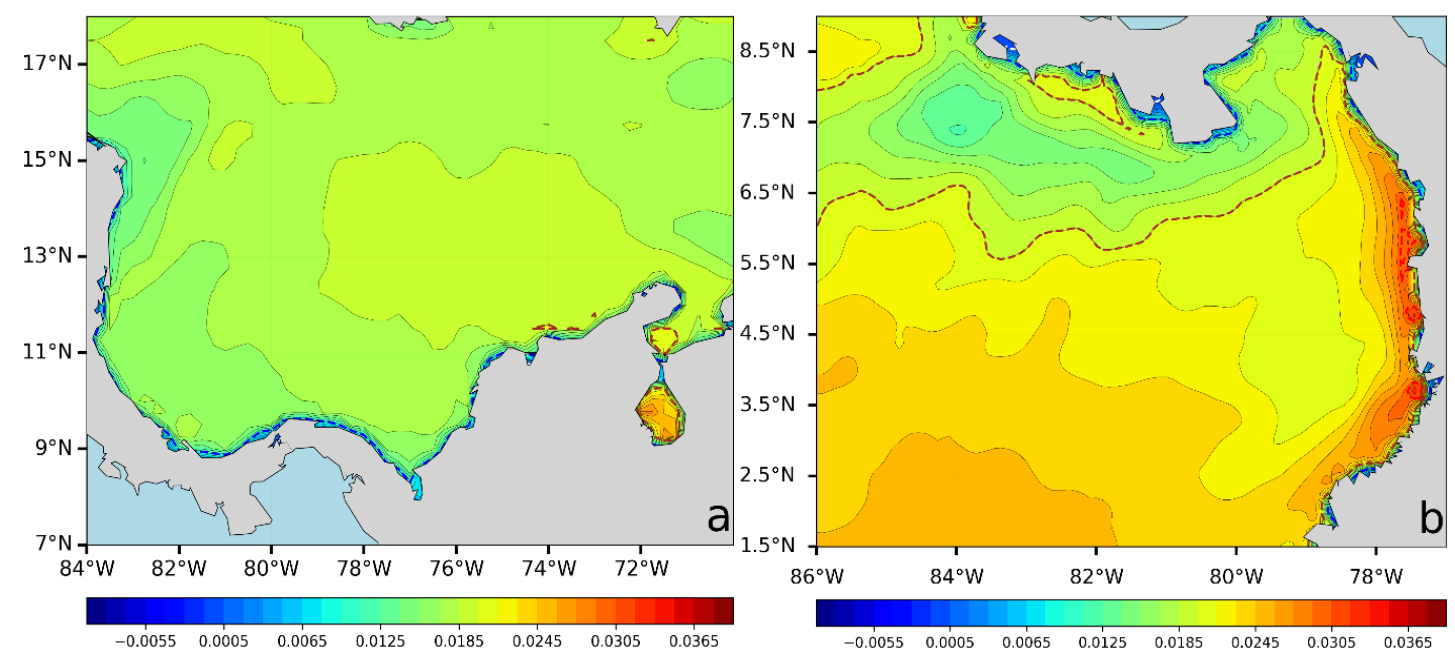

Figure 7. The multi-annual linear trend of sea surface temperature $\left({ }^{\circ} \mathrm{C}^{-1}\right)$ from Regional Ocean Modeling System (ROMS) data 2008-2035 period. Significant for 95\% confidence level. a) Colombian Caribbean Sea, b) Colombian Pacific

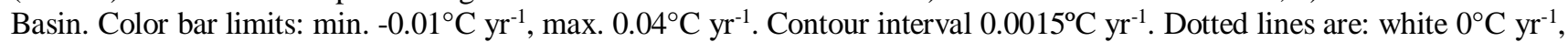
blue $0.01^{\circ} \mathrm{C} \mathrm{yr}^{-1}$, brown $0.02^{\circ} \mathrm{C} \mathrm{yr}^{-1}$, red $0.03^{\circ} \mathrm{C} \mathrm{yr}^{-1}$.

sector divided into two parts, extending to $16^{\circ} \mathrm{N}-82^{\circ} \mathrm{W}$ and the other to $13^{\circ} \mathrm{N}-81^{\circ} \mathrm{W}$. There is a sector in the northwest part of the CCS above $17^{\circ} \mathrm{N}$, which extends up to $79^{\circ} \mathrm{W}$, highlighting positive trend values $\left(0.018^{\circ} \mathrm{C}\right.$ $\left.\mathrm{yr}^{-1}\right)$. The same values are observed in a territory extending from the La Guajira Peninsula towards the center of CCS and up to $15^{\circ} \mathrm{N}-79^{\circ} \mathrm{W}$. All the Caribbean coasts show trends less than $0.01^{\circ} \mathrm{C} \mathrm{yr}^{-1}$, which also occurs on the Pacific coast (Fig. 7b). There is a contrast with nearby positive high-trend waters along the coast $\left(0.03^{\circ} \mathrm{C} \mathrm{yr}^{-1}\right)$ extending to $0.5^{\circ}$ off-shore in the CPB.
This spatial distribution could represent the homogeneous coastal zones CCSW and WCSW, shown in Figure $3 \mathrm{~b}$. The sector located between 6 and $8^{\circ} \mathrm{N}$ surrounding Central America (Fig. 7b) presents a positive trend that decreases from 0.02 to $0.012^{\circ} \mathrm{C} \mathrm{yr}^{-1}$. Sectors with high positive trends are northwest $\left(0.024^{\circ} \mathrm{C} \mathrm{yr}^{-1}\right)$ and southwest $\left(0.027^{\circ} \mathrm{C} \mathrm{yr}^{-1}\right)$. From the southwest, the values decrease to $0.02^{\circ} \mathrm{C} \mathrm{yr}^{-1}$, covering the $\mathrm{CPB}$ up to $6^{\circ} \mathrm{N}-79^{\circ} \mathrm{W}$, even reaching the Colombian-Panamanian coast. 

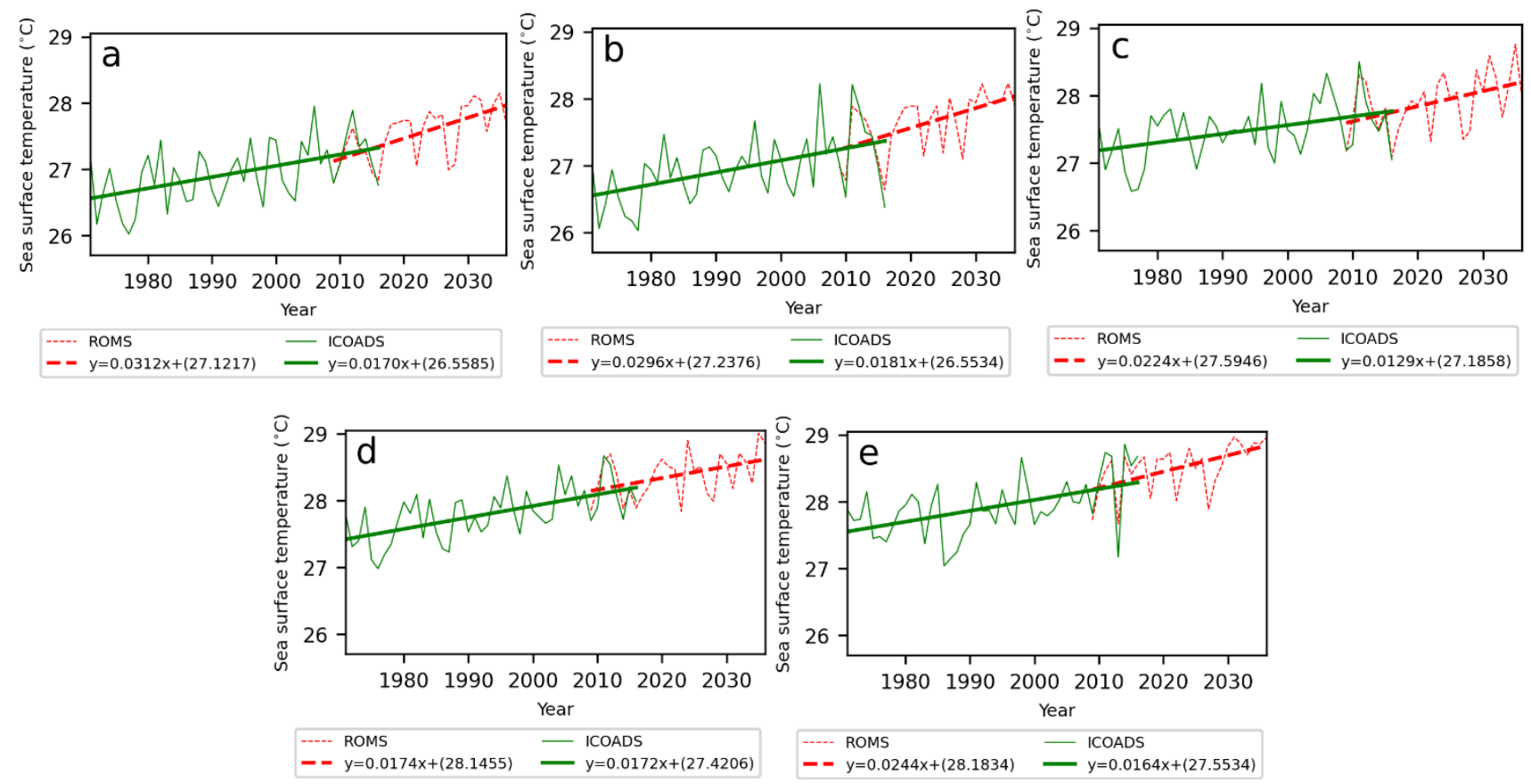

Figure 8. Sea surface temperature series $\left({ }^{\circ} \mathrm{C}\right)$ from International Comprehensive Ocean-Atmosphere Data Sets (ICOADS) (1970-2015) and Regional Ocean Modeling System (ROMS) (2008-2035) at insular and continental coastal stations of the Colombian Caribbean Sea. Significant for 95\% confidence level. a) Punta Gallinas, b) Portete Bay, c) Tayrona Park, d) Rosario Island, e) Providencia Island. ICOADS: solid lines. ROMS: dotted lines.

According to ICOADS for 1970-2007, the described spatial distribution shows that both regions present a similar positive trend (spatial average of $0.01^{\circ} \mathrm{C} \mathrm{yr}^{-1}$ ) but highlight greater warming in neither one of them. On the other hand, ROMS data for the 2008-2035 period presented differences in the spatial distribution of trends between the two regions. Likewise, the average spatial trend for CCS $\left(0.01^{\circ} \mathrm{C} \mathrm{yr}^{-1}\right)$ prescribes that the general warming of CCS will be less than that of CPB $\left(0.02^{\circ} \mathrm{C} \mathrm{yr}^{-1}\right)$ up to 2035 .

Taking into account a longer observation period (1970-2015) and only for continental and insular stations on the Colombian coasts, we appreciate that all of them present positive trends both with ICOADS data (Figs. 8-9, solid lines) and ROMS (Figs. 8-9, dotted lines).

Stations over CCS for the 1970-2015 period show that SST tendencies are greater (Fig. 8) than over CPB (Fig. 9) with an average trend of 0.016 and $0.013^{\circ} \mathrm{C} \mathrm{yr}^{-1}$, respectively (Table 3 ). When comparing trends for CCS stations between the 1970-2015 period from ICOADS (Fig. 8, solid lines) and the 2008-2035 period from ROMS (Fig. 8, dotted lines), it is found that the average in ROMS $\left(0.025^{\circ} \mathrm{C} \mathrm{yr}^{-1}\right)$ is greater than in ICOADS $\left(0.016^{\circ} \mathrm{C} \mathrm{yr}^{-1}\right)$. SSTs series simulated for CCS by ROMS (2008-2035) shows that the stations with the lower positive trend are TP and RI, located close to the Magdalena and Sinú rivers' mouths. The stations with the greater positive trend are PG and PB, showing a strong trend towards high SST values in waters close to the La Guajira Peninsula by the end of 2035.

According to ICOADS in CPB for 1970-2015, the station with the lowest increasing positive slope was $\mathrm{SB}$, and with the highest was MI (Table 3 ). The average trend increase in the $\mathrm{CPB}$ stations is $0.013^{\circ} \mathrm{C} \mathrm{yr}^{-1}$ with ICOADS and $0.015^{\circ} \mathrm{C} \mathrm{yr}^{-1}$ according to ROMS 20082035 period. SSTs series simulated for CPB by ROMS (2008-2035) shows that the station with a lower positive trend is BP, located in the San Juan River's mouth. According to ROMS, the station with the highest increasing positive slope is MI, located in the middle of the CPB. It means that by the end of 2035 , these waters could show a strong trend towards high SST values.

Decade trends were calculated to determine differences in SST trends at the stations during the observation periods. Table 4 shows that with ICOADS data, the CCS stations present a slight SST increase in $1970-1979\left(0.02^{\circ} \mathrm{C}\right.$ decade $^{-1}$ in PG and $0.12^{\circ} \mathrm{C}$ decade $^{-1}$ in $\mathrm{PB})$. Decreasing trends are observed in the 80s, except for BP $\left(0.14^{\circ} \mathrm{C}\right.$ decade $\left.^{-1}\right)$. In the 1990 s, CCS 

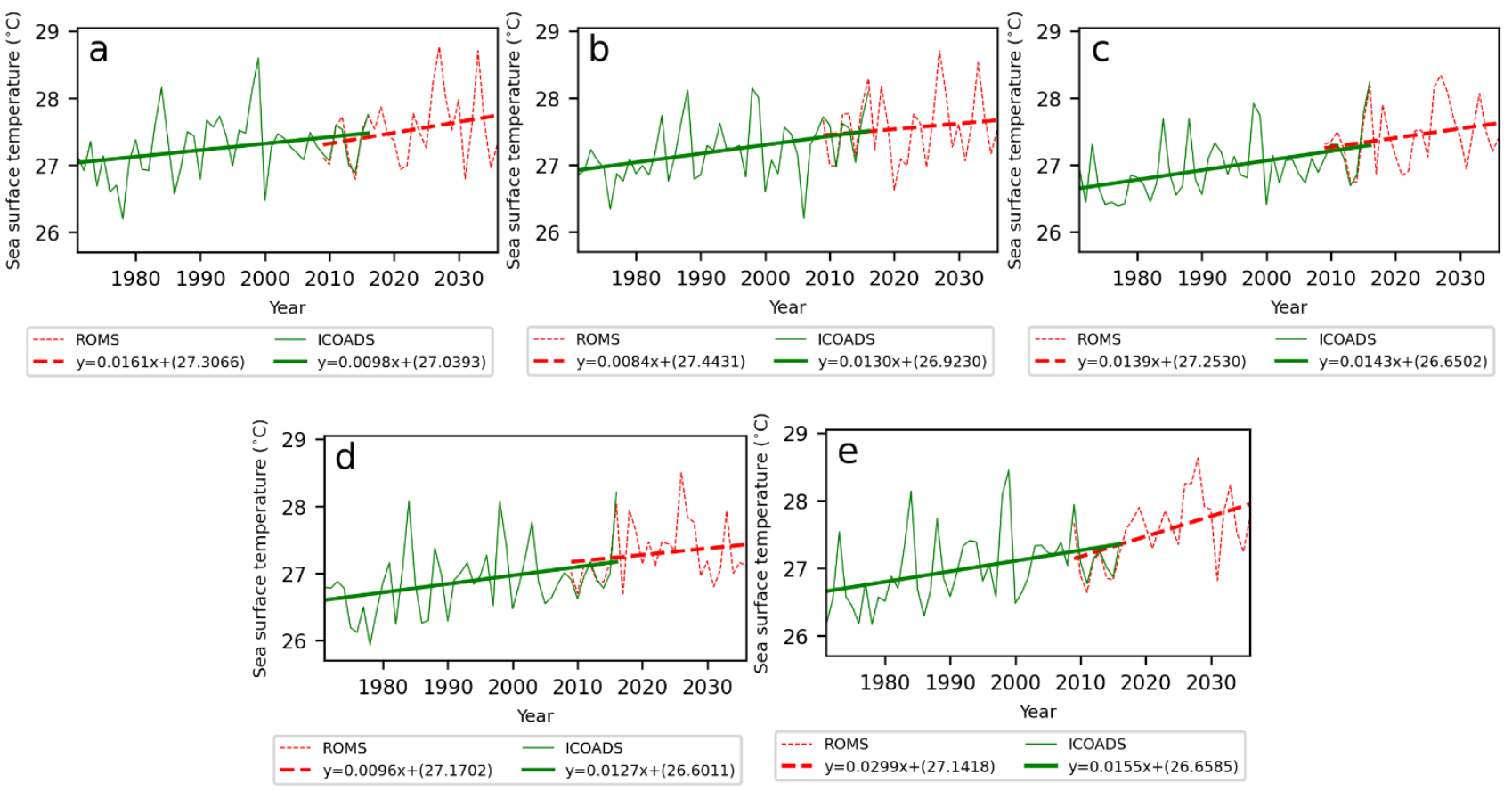

Figure 9. Sea surface temperature series $\left({ }^{\circ} \mathrm{C}\right)$ from International Comprehensive Ocean-Atmosphere Data Sets (ICOADS) (1970-2015) and Regional Ocean Modeling System (ROMS) (2008-2035) at insular and continental coastal stations of the Colombian Pacific Basin. Significant for 95\% confidence level. a) Solano Bay, b) Buenaventura Port, c) Gorgona Island, d) Tumaco Port, e) Malpelo Island. ICOADS: solid lines. ROMS: dotted lines.

stations showed a sharp increase in SST, with PG and PB standing out $\left(0.69\right.$ and $0.37^{\circ} \mathrm{C}$ decade $^{-1}$, respectively). In the following decade (2000-2009), the trend increase continued although less intensity, especially in TP $\left(0.04^{\circ} \mathrm{C}\right.$ decade $\left.^{-1}\right)$. Table 5 shows that in $1970-1979$, the SST trends for the CPB stations, according to ICOADS, are negative. In the 80 s, only BP and GI trends in the CPB increased $\left(0.18\right.$ and $0.15^{\circ} \mathrm{C}_{\text {decade }}{ }^{-1}$, respectively). In the 90s, trends in SB and GI decreased, but in MI $\left(0.31^{\circ} \mathrm{C}\right.$ decade $\left.^{-1}\right)$, TPo $\left(0.18^{\circ} \mathrm{C}\right.$ decade $\left.^{-1}\right)$, and BP $\left(0.04^{\circ} \mathrm{C}\right.$ decade $\left.^{-1}\right)$ stations increased. In the 2000-2009 decade, the stations with positive SST trends are MI $\left(0.62^{\circ} \mathrm{C}\right.$ decade $\left.^{-1}\right)$, BP $\left(0.54^{\circ} \mathrm{C}\right.$ decade $\left.^{-1}\right)$ and GI $\left(0.19^{\circ} \mathrm{C}\right.$ decade $\left.^{-1}\right)$. The decadal SST trends calculated from ROMS for the CCS stations (Table 4) present in 2010-2019 positive values only for PG $\left(0.36^{\circ} \mathrm{C}\right.$ decade $\left.^{-1}\right)$ and PI $\left(0.23^{\circ} \mathrm{C}\right.$ decade $\left.^{-1}\right)$. In 2020 2029 decadal SST trends are positive, with low values in TP, RI, and PI. The decadal SST trends calculated with ROMS data for the CPB stations (Table 5) show positive values except for BP. High values are presented in MI, TPo, and GI stations $(1.17,0.57$ and $0.30^{\circ} \mathrm{C}_{\text {decade }}{ }^{-1}$, respectively). In the $2020-2029$ decade, all stations present a positive trend with high values except TPo.

Although spatially ROMS evidences higher positive trends in the CPB than those of the CCS by 2035, the continental and insular coast stations behave differently. It was found by reviewing trends in the periods 1970-2007 with ICOADS data and 2008-2035 with ROMS data, as well as by reviewing trends in the decades 1970-1979, 1980-1989, 1990-1999, 20002009 (ICOADS) and 2010-2019, 2020-2029 (ROMS). This review, carried out only for coastal and insular stations, allows us to say that in 2020-2029, the positive trend in CPB stations is greater than in CCS, except for Tpo, which presents a very low positive trend. By 2035, CCS stations evidence a higher positive trend than the CPB stations, except for MI, which shows a very high trend.

\section{DISCUSSION}

\section{Comparison between SST simulated with ROMS in the recent past and observed data for the CCS through deviation measures}

The sectors with lower bias (Fig. 4) are situated where the ocean responded to global and regional processes, but not to local ones. Atmospheric forcing introduced into ROMS allows to simulation in CCS the general characteristics identified by Ruiz-Ochoa et al. (2012) and Pareja et al. (2013) as CWP and CCP (Fig. 3a) but soften the influence of local meteorological and continental factors that have been described by Restrepo 


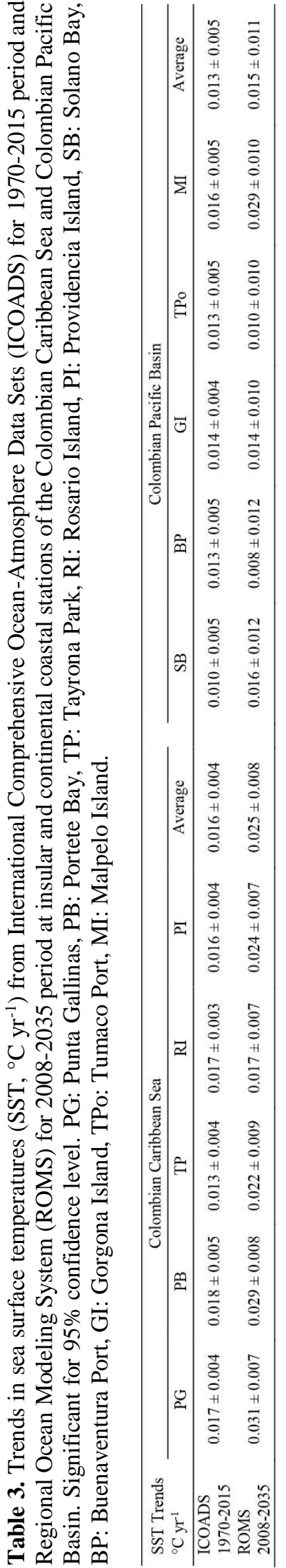

\& Kjerfve (2004), Poveda et al. (2006) and Whyte et al. (2008), among others. These factors are the CLLJ and the northeast trade winds, which generate the LGU, where cold waters were located (Rueda-Roa \& MullerKarger 2013). Low SST amplitude values obtained in the ROMS series (Table 1), especially for PG and PB, show that the model failed to reconstruct significant SST variations in these stations. They are located to the north-east of the La Guajira peninsula, exposed to cold fronts (Ortiz-Royero et al. 2013), receiving strong winds frequently during El Niño (Bernal et al. 2016), which explains the high SST amplitude presented in ICOADS and OSTIA series for PG and PB. Sectors with higher bias allow us to infer that there is a need to improve the response to local phenomena, especially around the Panamanian coast in the CCS, where jet winds' role is important (Wang 2007). This fact can also be appreciated by the different deviation measurement values obtained in the PB station compared to the other stations (Table 2). PB is situated where variations in both SST and SSS are perceived (Rodríguez 2011). These variations respond to the atmospheric pressure system that generates a change in the wind direction towards the north from the coast analyzed by Lonin et al. (2010), who concluded that this causes the interruption of LGU. Table 2 shows at PB the lowest ME value obtained and the highest CMD, MAE, and EC coefficients.

On the other hand, the deviation measures in RI showed a perfect fit between the observed and modeled series, also reflected in the SST amplitude values' similarity (Table 1), maybe since RI is located in the central sector of the Caribbean coast. In this sector, the distribution of northeast-southwest SSTs parallel to the coast (Pareja et al. 2013) represents a continuous mixing of two surface water masses: cold water from the north-east (LGU) and warm water from the southwest of the Caribbean coast (coming from Panama). Around RI, the mixing waters (Rodríguez et al. 2010) soften SST oscillations which could be simulated with ROMS. Figure 4a (bias with ICOADS data) shows that the SST located in cold and saline waters as well as the SST located in warm and less saline waters (Gulf of Darién) known as CCP and CWP, respectively (Ricaurte-Villota \& BastidasSalamanca 2017), have been well represented in the simulation. OSTIA has a high spatial resolution and shows the SST of the ocean's surface skin, while ICOADS represents data from the oceanic layer's first meters, which ROMS reproduces. Both biases with ICOADS and OSTIA presented positive values, especially at LGU in OSTIA. Although general SST patterns have been well simulated with ROMS, local characteristics' representation needs to be improved, as 
Table 4. Decadal trends in sea surface temperatures (SST, ${ }^{\circ} \mathrm{C}$ decade ${ }^{-1}$ ) from International Comprehensive OceanAtmosphere Data Sets (ICOADS) and Regional Ocean Modeling System (ROMS) at insular and continental coastal stations of the Colombian Caribbean Sea. PG: Punta Gallinas, PB: Portete Bay, TP: Tayrona Park, RI: Rosario Island, PI: Providencia Island. Significant for 95\% confidence level.

\begin{tabular}{lcccccc}
\hline \multirow{2}{*}{ Series SST trends $\left({ }^{\circ} \mathrm{C}\right.$ decade $\left.{ }^{-1}\right)$} & \multicolumn{5}{c}{ Colombian Caribbean Sea } \\
\cline { 3 - 7 } & $1970-1979$ & $0.02 \pm 0.05$ & $0.12 \pm 0.05$ & $0.07 \pm 0.05$ & $0.10 \pm 0.04$ & $-0.07 \pm 0.03$ \\
\multirow{3}{*}{ ICOADS } & $1980-1989$ & $-0.01 \pm 0.04$ & $0.14 \pm 0.4$ & $-0.35 \pm 0.03$ & $-0.19 \pm 0.04$ & $-0.70 \pm 0.04$ \\
& $1990-1999$ & $0.69 \pm 0.04$ & $0.37 \pm 0.04$ & $0.02 \pm 0.04$ & $0.27 \pm 0.03$ & $0.02 \pm 0.04$ \\
& $2000-2009$ & $0.41 \pm 0.05$ & $0.27 \pm 0.06$ & $0.04 \pm 0.05$ & $0.13 \pm 0.04$ & $0.36 \pm 0.02$ \\
\hline \multirow{2}{*}{ ROMS } & $2010-2019$ & $0.36 \pm 0.03$ & $-0.004 \pm 0.05$ & $-0.43 \pm 0.04$ & $-0.12 \pm 0.04$ & $0.23 \pm 0.04$ \\
& $2020-2029$ & $0.18 \pm 0.05$ & $0.20 \pm 0.04$ & $0.06 \pm 0.05$ & $0.03 \pm 0.04$ & $0.06 \pm 0.04$ \\
\hline
\end{tabular}

Table 5. Decadal trends in sea surface temperatures $\left({ }^{\circ} \mathrm{C}\right.$ decade $\left.^{-1}\right)$ from International Comprehensive Ocean-Atmosphere Data Sets (ICOADS) and Regional Ocean Modeling System (ROMS) at insular and continental coastal stations of Colombian Pacific Basin. SB: Solano Bay, BP: Buenaventura Port, GI: Gorgona Island, TPo: Tumaco Port, MI: Malpelo Island. Significant for 95\% confidence level.

\begin{tabular}{|c|c|c|c|c|c|c|}
\hline \multirow{2}{*}{\multicolumn{2}{|c|}{ Series SST trends $\left({ }^{\circ} \mathrm{C}\right.$ decade $\left.^{-1}\right)$}} & \multicolumn{5}{|c|}{ Colombian Pacific Basin } \\
\hline & & SB & $\mathrm{BP}$ & GI & TPo & MI \\
\hline \multirow{4}{*}{ ICOADS } & 1970-1979 & $-0.19 \pm 0.04$ & $-0.13 \pm 0.03$ & $-0.23 \pm 0.04$ & $-0.45 \pm 0.04$ & $-0.20 \pm 0.05$ \\
\hline & 1980-1989 & $-0.16 \pm 0.06$ & $0.18 \pm 0.06$ & $0.15 \pm 0.05$ & $-0.42 \pm 0.07$ & $-0.27 \pm 0.07$ \\
\hline & 1990-1999 & $-0.06 \pm 0.07$ & $0.04 \pm 0.06$ & $-0.01 \pm 0.05$ & $0.18 \pm 0.05$ & $0.31 \pm 0.07$ \\
\hline & 2000-2009 & $-0.24 \pm 0.02$ & $0.54 \pm 0.05$ & $0.19 \pm 0.02$ & $-0.49 \pm 0.04$ & $0.62 \pm 0.03$ \\
\hline \multirow{2}{*}{ ROMS } & $2010-2019$ & $0.16 \pm 0.04$ & $-0.09 \pm 0.06$ & $0.30 \pm 0.06$ & $0.57 \pm 0.05$ & $1.17 \pm 0.03$ \\
\hline & 2020-2029 & $1.16 \pm 0.05$ & $0.74 \pm 0.09$ & $1.04 \pm 0.05$ & $0.01 \pm 0.05$ & $0.87 \pm 0.04$ \\
\hline
\end{tabular}

in LGU. Turuncoglu et al. (2013) came to this same conclusion using the coupling of the atmospheric RegCM4 model and the oceanic ROMS model to simulate the Caspian Sea for the 1999-2008 period. They represented SST, SSS, and currents' general characteristics but did not manage to represent the upwelling zone's features on the east coast and failed to obtain an adequate SL. Likewise, Machu et al. (2015) highlight the need to adjust global models to regional characteristics analyzing results of the simulation of Benguela upwelling with ROMS.

\section{Comparison between SST simulated with ROMS in the recent past and observed data for the CPB through deviation measures}

Bias in Figure 5 exposes that the ROMS model has done a better job of simulating the characteristic distribution of SST in the CPB, giving lower bias values than those obtained in CCS. In the CPB central sector, it was possible to represent longitudinal coastal (CCSW and WCSW), mixed (SMW and CSW) and oceanic (TSW) zones (Fig. 3b), resulting from the dynamics of turns and currents such as PBCG, CoC and NECC (Fig. 2b) (Malikov et al. 2010). Likewise, in the $\mathrm{CPB}$, it was possible to distinguish the coastal north- south SST contrast generated by changes in the circulation pattern due to predominant atmospheric forcings at a regional scale, such as the northern jet of Panama and the ChLLJ (Rodríguez-Rubio et al. 2003, Devis-Morales et al. 2008). The constant values of rivers introduced into ROMS might cause the bias to be negative in some Pacific coast sectors, where the fluvial factor is important (CCCP 2002). In this coastal sector, the greatest SST amplitude according to observed data corresponds to SB (Table 1), located where there are large amounts of fluvial discharges (Restrepo 2006) influenced by atmospheric processes, such as the reversal of winds studied by Poveda \& Mesa (2000), and Rueda \& Poveda (2008). According to ICOADS and ROMS (Table 1), the SST amplitude of GI shows the lowest variability in the CPB. GI is located where oceanic water masses flow with the NECC (Kessler 2006) and then become the $\mathrm{CoC}$ that flows parallel north along the Colombian Pacific coast (Villegas \& Malikov 2006). These waters, represented in GI and TPo, form part of the SMW where constant mixing waters occur, conserving homogeneous thermohaline characteristics, reflected in these stations' SST amplitude (Table 1). This sector presents a low negative bias (Fig. 5) and shows good deviation measures 
corresponding to GI and TPo (Table 2). ROMS has well represented these cold waters, resulting from the upwelling and downwelling cycles generated during the ITCZ displacement over the CPB (Díaz et al. 2008).

The average SST of ICOADS and ROMS in the CPB (Table 1) are closer than in CCS. It could be that CCS is greatly influenced by local atmospheric and hydrographic processes (Lonin et al. 2010, Restrepo et al. 2014), generating more differences between the observed SST and the series obtained by ROMS. Instead, the CPB exchanges its waters with the open ocean (Villegas \& Malikov 2009) and is influenced by global and regional processes (Wallace et al. 1989, Zhang et al. 2010, Zheng et al. 2012, Villegas et al. 2016), which appear to be reflected in the initial, boundary and forcing conditions given to ROMS. Although these factors allowed achieving better results in CPB than in CCS, we have to consider the conclusions of Sierra et al. (2018), who evaluated the ability to simulate the ChLLJ of coupled and uncoupled GCMs included in CMIP5. They found that some of these models present biases in ITCZ location over the eastern tropical Pacific Ocean. Therefore, the bias that GCMs bring when used as initial and border conditions influences regional simulations. In this CCS and CPB simulation, initial conditions and forcing introduced in ROMS brought with them global and regional factors making it possible to represent the spatial and temporal distribution of SST in both regions. However, it is essential to carry out new runs including local information to obtain more precise results, to improve the capacity to represent the study areas' thermohaline and dynamic fields. An improved response to local phenomena could be obtained through data assimilation and the use of both atmospheric forcing and continental boundary conditions with higher resolution.

\section{SST trends in the Colombian Caribbean Sea (CCS) and Colombian Pacific Basin (CPB)}

As previously mentioned, the average spatial trend for CCS indicates that by 2035 the overall warming of CCS will be less than that of CPB. Whyte et al. (2008) analyzed the dependence of Equatorial Pacific warming and Tropical Atlantic cooling on the location and strengthening or weakening CLLJ. Looking at Figure $7 \mathrm{a}$, in the spatial distribution of SST trends in CCS (ROMS, 2008-2035), there are two demarcated sectors: one of low positive trends on the Central American coast, which extends northeast and southwest, and another of high positive values around the La Guajira Peninsula, which extends northwest reaching the center of CCS. Considering the dependence analyzed by Whyte et al. (2008), this distribution in CCS could be explained by a possible variation in location and CLLJ intensity (strengthening or weakening) to 2035 , suggesting an SST horizontal gradient increase between the two basins, irrespective of which ocean is driving the difference. We suggest that atmospheric forcing (RegCM4.1 of RCP4.5) introduced into our numerical experiments reflects a weak CLLJ, causing positive trend values in the sector known as CCP in the CCS (Fig. 3a). About the strengthening or weakening of CLLJ in the future, there are disagreements. Diro et al. (2012) compared multi-annual simulations over the Central America CORDEX domain conducted with RegCM4 driven by ERA-Interim reanalysis fields. The authors found that the CLLJ location is simulated reasonably well by 3 model versions, although the simulated jet strength is weaker than ERA-Interim reanalysis, and it is located slightly too far south, with the core around $12^{\circ} \mathrm{N}$. A vertical cross-section of zonal winds at $75^{\circ} \mathrm{W}$ revealed that CLLJ is slightly stronger in the CLM simulation of RegCM4. Taylor et al. (2013) assessed the wind in $925 \mathrm{hPa}$, where the core of CLLJ is located, and found strengthening of winds based on PRECIS projections for A2 and B2 scenarios toward the end of the century. Fuentes-Franco et al. (2015) compared observed atmospheric data with different RegCM4 configurations for the control period of the 1970-2100 projection for RCP8.5 scenarios. One of those, called Em+CLM, is the configuration of atmospheric forcing used in the present work (but for RCP4.5). The second configuration, called Gr+BATS, used the scheme of Grell (1993) for convection and the Biosphere-Atmosphere Transfer Scheme (BATS) of Dickinson et al. (1993) for land surface processes. The authors found that Em+CLM configuration showed patterns more in line with observed precipitation (Pr) and a future change in interannual variability of $\mathrm{Pr}$ towards a much greater occurrence of very dry seasons over Southern Mexico and Central America. Greater warming of the Tropical Northeastern Pacific (TNP) compared to the Tropical North Atlantic (TNA), which causes stronger wind fluxes from the TNA to the TNP through CLLJ, was identified as the main process responsible for these drier conditions. However, Imbach et al. (2018) mentioned that the wind in 925 $\mathrm{hPa}$, where the CLLJ core is located, weakens during the entire year in projections for the 2021-2050 period from Eta RegCM, driven by HadGEM2-ES simulations of RCP4.5 scenarios.

Positive trends with the highest value in CCS are seen not only in the CCP (Fig. 7a) and also in waters corresponding to LGU, which might indicate that by 2035, as was pointed by Imbach et al. (2018), a CLLJ weakening could be expected, contributing to the increase in SST of the upwelling sector. According to Wang (2007), when the North Atlantic Subtropical 
High (NASH) is strong and extends westward, the easterly CLLJ is strengthened, resulting in an SST decrease in the CLLJ area and in the western TNA. When NASH is weak, this pattern is reversed, and thus it can be suggested that a weakening of NASH will prevail in the near future. Whyte et al. (2008) suggest that, under the El Niño scenario (which is not discussed in this paper), the strong winds zone extends further northward and deeper into the southwestern Caribbean basin. These assessments point to the Caribbean dynamic structure complexity, making it essential for local factors to be taken into account alongside regional and global ones to accurately understand the area and model.

In CPB (Fig. 7b), excluding negative trends observed in the small coastal areas characterized by marked rivers influx from the Andes (Restrepo 2006), positive trends are found throughout the region. Higher positive trends are in 1) the WCSW zone (Malikov et al. 2010), 2) south of the CPB where oceanic waters (ESW) arrive as part of the NECC (Chaigneau et al. 2006), and 3) in upwelling areas observed all year round (Villegas et al. 2016) named CCSW. Biasutti et al. (2012), when comparing simulations between North American Regional Climate Change Program (NARCCAP) and IPCC AR4 projections, pointed that future climate will resemble an El Niño event, implying weakening of tropical atmospheric circulation in response to warming. This resembles ROMS obtained in the present work about positive trends up to 2035 throughout CPB. On the other hand, the El Niño event leads to CLLJ strengthening (Whyte et al. 2008), which does not agree with ROMS results for CCS.

Regarding data used as forcing and boundary conditions, Fuentes-Franco et al. (2015) found that mean SST change (2070-2099 minus 1976-2005) exhibits greater SST warming over the Pacific that over the TNA in both HadGEM and MPI models. Sierra et al. (2018) assessed the potential of CMIP5 models to simulate the ChLLJ and found biases in the representation of ChLLJ and ITCZ location, affecting the regional ocean's good fit models. Among the evaluated models are MPI-ESM and HadGEM, which were classified as the "best". In our experiment (20082035 for CPB), the southwest sector was the most affected in the simulation, since although it is related to the cold tongue that reaches CPB, ROMS representation suggests a warming of that sector which could be due not only to atmospheric forcing that suggests future scenarios similar to El Niño event but also to boundary conditions. The present results confirm that the continuous improvement in the representation of atmospheric local circulation particularities and understanding the region's dynamic is one of the key points for obtaining better simulation in regional ocean models.

\section{SST trends in continental and insular coastal waters over CCS and CPB}

Differences in SST trends between PG, PB, and TP are appreciated (Fig. 8, Table 3). Although these stations are close to each other in CCS, the eastern zone is influenced by stronger winds causing a high turbulence level (Rueda-Roa \& Muller-Karger 2013), which implies differences in SST and differentiation in responses to climate change. Therefore, for each simulated sector, it is necessary to consider local factors that govern the atmospheric and oceanic circulation. Carmona \& Poveda (2014) found that climatic variability in tropical South America can generate differentiation in Pr trends in Colombian continental region, affecting the SST trends if this data is used as atmospheric forcing in an oceanic regional model. The differentiation in SST simulation over the CCS can also occur because of the coastal topography, where Sierra Nevada de Santa Marta (SNSM) marks a great contrast in its meteorological behavior. Veloza (2017) this author used Ta and Pr of the 1985-2016 period to classify the climate of seven cities located along the Colombian Caribbean coast, from "San Lorenzo", near the SNSM where TP is located, up to "Manaure", situated a little further south of PB. Veloza (2017) concluded that without the presence of the SNSM, the Colombian Caribbean coast's climate would be arider and more similar to the climate of La Guajira Peninsula, meaning that the coastal topography is an important factor that must be taken into account in the atmospheric circulation interposed in a regional ocean model for the CCS. Analyzing the possible factors that may contribute to SST underestimation in LGU simulation, Lonin et al. (2010) also mention that clouds effects and water vapor are more noticeable in CCS coastal areas, where high elevations such as SNSM obstruct the trade winds and contribute to topographic cloud formation, a factor which influences the SST.

A very important aspect to consider for trends in CPB (Fig. 9, Table 3) is the continuous feedback in interrelations between Pr and SST. It is well known that variations in $\operatorname{Pr}$ and SST's spatial distributions are closely connected so that, on average, $\mathrm{Pr}$ is higher where SST is also higher. In the CPB, low-level circulation is dominated by ChLLJ (Poveda et al. 2014). ChLLJ brings a large amount of moisture toward Central America and northern South America. Gallego et al. (2019), with an index representative of ChLLJ, developed using wind direction data from ICOADS, showed that when ChLLJ is weak, the SST in the region is warm. It could indicate that in the present 
experiment, the SST obtained with ROMS for CPB appears to be the result of a weak ChLLJ. Since each model will always represent the same simulated region's characteristics differently, various aspects need to be considered when performing a simulation. For example, Sierra et al. (2015), evaluating the capacity of seven different CMIP5 models to represent seasonal Pr and its interannual variability in northern South America, pointed that models were better at representing the Pr distribution over oceans and land during summer and autumn, but gave their worst simulations during winter and spring. The authors suggest that models that best represented the oceanic ITCZ and ChLLJ could realistically simulate the main features of seasonal Pr patterns over the region, among which HadGEM stood out.

In the CPB's performed simulation with ROMS, two factors can be distinguished from the stations' geographical locations. The SST in waters near SB is influenced by an increasing trend of Pr, associated with the decrease in strength of ChLLJ. Regarding the MI, the SST is influenced by the constant north-south migration of ITCZ. The RegCM4 run with RCP4.5 contains the highest $\operatorname{Pr}$ precisely in the Central American region (Giorgi et al. 2012), which means that these two atmospheric factors are immersed in the atmospheric forcing introduced in ROMS up to 2035 (coming from the RegCM4 run with RCP4.5), which influences the resulting SST in the continental and insular coastal stations in CPB. Also, Biasutti et al. (2012) observed that a strong increase in Pr is projected near-the equatorial regions of the eastern Pacific and Atlantic, as opposed to a decrease in most of the Caribbean and Gulf of Mexico, which will affect future SST distributions. The key to improving the CPB projection is related to the open boundary information introduced rather than the atmospheric forcing.

As in the CCS, change rates in SST for CPB are higher in ROMS data (2008-2035) compared to ICOADS (1970-2015), although differences are not as marked as in CCS (Figs. 8-9, Table 3). In addition to the factors mentioned above, this may be because the Caribbean dynamics are highly unstable, as was shown by Jouanno et al. (2008) and after Jouanno \& Sheinbaum (2013). These authors pointed out the strong dynamic differences between Colombia, Venezuela, and Cayman basins with a numerical study. They found that baroclinic eddies located in the Lesser Antilles get wider, deeper, and stronger moving westward to the Colombian basin. They suggest that kinetic energy variability is highest in the Colombia and Venezuela basins. Likewise, the study carried out by Pérez \& Calil (2017) confirms that when modeling the oceanic circulation of CCS, great attention should be paid to the La Guajira Peninsula and the Lesser Antilles since their dynamics are related to energy transfer. The transfer of kinetic energy from large to small scales is due to submesoscale vorticity filaments formed in the interaction of North Brazil Current (NBC) rings with the islands.

The consequence of global warming on the warm and cold pools of the ocean, explained by An et al. (2012), makes sense for what was observed in the distribution of SST in CCS and CPB. Global warming initially brings a stronger warming trend over the tropical Pacific's warm pool than in the cold SST tongue region. As the ocean subsurface temperatures increase, the vertical temperature gradient decreases cause that surface cooling by upwelling to weaken. Consequently, the net thermal damping could decrease, causing the cold tongue's heating to exceed, eventually, that of the warm pool (An et al. 2012). The effect would be valid for CCS and CPB where cold and warm pools exist and which has indeed been observed in this investigation in LGU. According to IPCC (2014), the upper ocean layer located in the average thickness of 75 $\mathrm{m}$ recorded a warming of great intensity, around $0.011^{\circ} \mathrm{C} \mathrm{yr}^{-1}$ for the $1971-2010$ period on average. The global ocean value differs from one geographic sector to another, as registered for CCS and CPB, both according to ICOADS as projected up to 2035 by ROMS, confirming the importance of differentiating between regions and taking local processes into account when carrying out simulations. Indeed, this study's findings, placed alongside comparisons between models, suggest that a global or regional climate change pattern cannot simply be imposed for local sectors. That numerical simulation must go hand in hand with a better understanding of teleconnections between oceanatmospheric processes of different spatial and temporal scales that influence climate and climatic variability in a given study area. The results of statistical downscaling from CMIP5 data with RCP6.0 presented in IDEAM (2017) indicate an average annual SST increase in the 2011-2040 period of $0.5^{\circ} \mathrm{C}$ for CCS and $0.7^{\circ} \mathrm{C}$ for $\mathrm{CPB}$, which differs from the present investigation, where according to ROMS results for the 2011-2035 period, the average SST increase for Colombia's continental and insular coastal stations analyzed in CCS would be $0.43^{\circ} \mathrm{C}$ and in CPB would be $0.31^{\circ} \mathrm{C}$. These values differ from IDEAM (2017), not only because of the years reviewed and the different RCPs but also because different methods were used to represent the results, one being based on statistical downscaling from a global model, while the present investigation is based on numerical modeling with ROMS, taking into account regional atmospheric forcing from RegCM4.1. Our results show the importance of continuing to analyze the ocean- 
atmospheric processes of different scales that interact in the study regions and develop new numerical experiments as follows: 1) extend the simulation domains to capture local dynamic processes, especially in the CCS, in order to visualize the influence of rings of the NBC on the variability of the Colombia basin dynamics, 2) increase the projected runs up to 2100 with atmospheric forcing and boundary conditions of RCP4.5 and RCP8.5 to differentiate the global warming effect on SST of cold and warm pools in the study regions, 3) improve atmospheric forcing to differentiate the influence on the SST of the ChLLJ, the CLLJ, the ITCZ, and the mesoscale processes that may arise between the SNSM and trade winds, and 4) in order to achieve an adequate representation of the regional climate using coupled and uncoupled simulations forced by reanalysis data and global model data, it is proposed to execute experiments for the CCS and CPB following methodologies similar to those carried out by Sitz et al. (2017) and Cabos et al. (2019).

\section{CONCLUSIONS}

The spatial distribution of SST trends from ICOADS (1970-2007) evidenced a similar increase in both the CCS and CPB. Although spatially SST simulated with ROMS (2008-2035) showed higher positive trends in the CPB than those of the CCS, the selected continental and insular coastal stations over CCS presented from ICOADS (1970-2015) and ROMS simulation (20082035) greater trends compared with those over CPB. The stations with greater positive trends up to 2035 are PG and PB, located in waters close to the La Guajira Peninsula and MI, located in the middle of the CPB.

For the 1970-2007 period, ROMS allows to simulate in CCS general characteristics as CWP and $\mathrm{CCP}$, but soften the influence of local meteorological and continental factors as CLLJ and the northeast trade winds, which generates coastal LGU. The simulation was better for $\mathrm{CPB}$, obtaining lower spatial bias values than those shown in CCS. It was possible to distinguish both the coastal SST north-south contrast generated by changes in the northern Panama jet's circulation pattern and the ChLLJ, as well as the coastal (CCSW and WCSW), mixed (SMW and CSW) and oceanic (TSW) zones.

For the 2008-2035 period, the spatial SST trend distribution in the CCS could be the result of a weak CLLJ introduced in the model by atmospheric forcing, which causes positive trend values in the sector known as CCP. The differentiation in SST simulation over the CCS can also occur because of the SNSM which marks a great contrast in the meteorological behavior and may contribute to underestimating the SST in the LGU. We must also pay attention to the oceanic circulation in $\mathrm{La}$ Guajira Peninsula and the Lesser Antilles since this dynamic is of great importance in the transfer of energy.

The distribution of SST trends in the CPB simulation for 2008-2035 evidences a SST warming due to the continuous feedback in interrelations between Pr and SST. In the CPB, low-level circulation is dominated by ChLLJ. Although in the present work, the atmospheric forcing introduced in ROMS comes from results of a regional model which present high $\mathrm{Pr}$ for the Central American region, the SST obtained for CPB seems to be the result of a weak ChLLJ.

The present results confirm that the continuous representation's improvement of the atmospheric local circulation particularities and understanding local oceanic dynamics is one of the key points for obtaining better simulation in regional ocean models. We suggest to carry out projections up to 2100 with atmospheric forcing and boundary conditions of RCP4.5 and RCP8.5 and to use coupled regional climate models to explore the global warming effect on SST of cold and warm pools in both Colombian marine regions.

\section{ACKNOWLEDGMENTS}

The authors wish to thank the Universidad Nacional de Colombia for supporting the Project $\mathrm{N}^{\circ} 37123$ with a grant, also the Earth System Physics (ESP) group of the Abdus Salam International Centre for Theoretical Physics (ICTP) for allowing the use of atmospheric and oceanic data resulting from RegCM and MPIOM respectively.

\section{REFERENCES}

An, S., Kim, J., Im, S., Kim, B. \& Park, J. 2012. Recent and future sea surface temperature trends in tropical pacific warm pool and cold tongue regions. Climate Dynamics, 39: 1373-1383. doi: 10.1007/s00382-0111129-7

Andrade, C. 2015. Oceanografía dinámica de la cuenca Colombia. Alpha Editores, Cartagena.

Andrade, C., Barton, E. \& Mooers, C. 2003. Evidence for an eastward flow along the Central and South American Caribbean Coast. Journal of Geophysical Research, 108: 3185. doi: 10.1029/2002JC001549

Bernal, G., Osorio, A., Urrego, L., Peláez, D., Molina, E., Zea, S., et al. 2016. Occurrence of energetic extreme oceanic events in the Colombian Caribbean coasts and some approaches to assess their impact on ecosystems. Journal of Marine Systems, 164: 85-100. doi: 10.1016/j.jmarsys.2016.08.007 
Biasutti, M., Sobel, A., Camargo, S. \& Creyts, T. 2012. Projected changes in the physical climate of the Gulf Coast and Caribbean. Climatic Change, 112: 819-845. doi: 10.1007/s10584-011-0254-y

Cabos, W., Sein, D.V., Durán-Quesada, A., Liguori, G., Koldunov, N., Martínez-López, B., et al. 2019. Dynamical downscaling of historical climate over CORDEX Central America domain with a regionally coupled atmosphere-ocean model. Climate Dynamics, 52: 4305. doi: 10.1007/s00382-018-4381-2.

Carmona, A. \& Poveda, G. 2014. Detection of long-term trends in monthly hydro-climatic series of Colombia through empirical mode decomposition. Climatic Change, 123: 301-313. doi: 10.1007/s10584-0131046-3

Centro de Investigaciones Oceanográficas e Hidrográficas del Pacífico (CCCP). 2002. Compilación oceanográfica de la cuenca pacífica colombiana. Naturaleza, Tumaco.

Comisión Colombiana del Océano (CCO). 2015. Construyendo país marítimo. Comisión Colombiana del Océano, Bogotá.

Chaigneau, A., Abarca del Rio, R. \& Colas, F. 2006. Lagrangian study of the Panama Bight and surrounding regions. Journal of Geophysical Research, 111: C09013. doi: 10.1029/2006JC003530

Devis-Morales, A., Schneider, W., Montoya-Sánchez, R. \& Rodríguez-Rubio, E. 2008. Monsoon-like winds reverse oceanic circulation in the Panama Bight. Geophysical Research Letters, 35: L20607. doi: 10.1029/2008GL035172

Díaz, D., Villegas, N. \& Málikov, I. 2008. Características de las zonas de surgencia de la cuenca del Pacífico colombiano y su relación con la Zona de Convergencia Intertropical. Boletín Científico CIOH, 26: 59-71. doi: 10.26640/22159045.181

Díaz, D., Villegas, N. \& Málikov, I. 2011. Análisis de la convergencia y la divergencia de Ekman en el Pacífico colombiano. Revista Colombiana de Física, 43: 653658.

Dickinson, R., Henderson-Sellers, A. \& Kennedy, P. 1993. Biosphere-atmosphere transfer scheme (BATS) version 1e as coupled to the NCAR Community Model (No. NCAR/TN-387+STR). University Corporation for Atmospheric Research, Colorado. doi: 10.5065/ D67W6959

Diro, T., Rauscher, S.A., Giorgi, F. \& Tompkins, A. 2012. Sensitivity of seasonal climate and diurnal precipitation over Central America to land and sea surface schemes in RegCM4. Climate Research, 52: 31-48. doi: $10.3354 / \mathrm{cr} 01049$
Departamento Nacional de Planeación (DNP). 2012. Plan nacional de adaptación al cambio climático, $\mathrm{ABC}$ : adaptación, bases conceptuales, marco conceptual y lineamientos. Imprenta Nacional de Colombia, Bogotá.

Donlon, C., Martin, M., Stark, J., Roberts-Jones, J., Fiedler, E. \& Wimmer, W. 2012. The operational sea surface temperature and sea ice analysis (OSTIA) system. Remote Sensing of Environment, 116: 140158. doi: 10.1016/j.rse.2010.10.017

Donohoe, A., Marshall, J., Ferreira, D. \& McGee, D. 2013. The relationship between ITCZ location and cross-equatorial atmospheric heat transport: from the seasonal cycle to the last glacial maximum. Journal of Climate, 26: 3597-3618. doi: 10.1175/JCLI-D-1200467.1

Emanuel, K. 1991. A scheme for representing cumulus convection in large-scale models. Journal of the Atmospheric Sciences, 48: 2313-2335. doi: 10.1175/ 1520-0469(1991)048<2313:ASFRCC > 2.0.CO;2

Eslava, J. 1993. Climatología y diversidad climática de Colombia. Revista de la Academia Colombiana de Ciencias Exactas, Físicas y Naturales, 18: 507-538.

Forsbergh, E. 1969. On the climatology, oceanography and fisheries of the Panama Bight. Inter-American Tropical Tuna Commission Bulletin, 14: 46-385.

Fuentes-Franco, R., Coppola, E., Filippo, G., Pavia, E., Tefera, G. \& Graef, F. 2015. Inter-annual variability of precipitation over southern Mexico and Central America and its relationship to sea surface temperature from a set of future projections from CMIP5 GCMs and RegCM4 CORDEX simulations. Climate Dynamics, 45: 425-440. doi: 10.1007/s00382-014-2258-6

Gallego, D., García-Herrera, R., Gómez-Delgado, F., Ordoñez-Pérez, P. \& Ribera, P. 2019. Tracking the moisture transport from the Pacific towards Central and northern South America since the late 19th century. Earth System Dynamics, 10: 319-331. doi: 10.5194/esd-10-319-2019

Giorgi, F., Coppola, E., Solmon, F., Mariotti, L., Sylla, M.B., Bi, X., et al. 2012. RegCM4: model description and preliminary tests over multiple CORDEX domains. Climate Research, 52: 7-29. doi: 10.3354/ cr01018.

Grell, G.A. 1993. Prognostic evaluation of assumptions used by cumulus parameterizations. Monthly Weather Review, 121: 764-787. doi: 10.1175/1520-0493(1993) $121<0764$ :PEOAUB>2.0.CO;2

Griffies, S. 2009. Elements of MOM4.1. GFDL Ocean Group Technical Report No. 6. NOAA Geophysical Fluid Dynamics Laboratory, Princeton.

Instituto de Hidrología, Meteorología y Estudios Ambientales (IDEAM). 2016. Datos abiertos. Catálogo 
nacional de estaciones del IDEAM. [https://www. datos.gov.co/Ambiente-y-Desarrollo-Sostenible/Catlogo-Nacional-de-Estaciones-del-IDEAM/hp9r-jxuu]. Reviewed: May 18, 2020.

Instituto de Hidrología, Meteorología y Estudios Ambientales (IDEAM). 2017. Tercera comunicación nacional ante la convención marco de las Naciones Unidas sobre cambio climático. Resumen Ejecutivo. IDEAM, Bogotá.

Imbach, P., Chou, S.C., Lyra, A., Rodrigues, D., Rodriguez, D., Latinovic, D., et al. 2018. Future climate change scenarios in Central America at high spatial resolution. Plos One, 13: e0193570. doi: 10.1371/journal.pone.0193570

Intergovernmental Panel on Climate Change (IPCC). 2014. Contribution of working groups I, II, and III to the Fifth Assessment Report of the Intergovernmental Panel on Climate Change. In: Pachauri, R. \& Meyer, L. (Eds.). The core writing team. Climate change 2014. Synthesis Report. IPCC, Geneva.

Joint Working Group on Forecast Verification Research (JWGFVR). 2009. Recommendations for the verification and intercomparison of QPFs and PQPFs from operational NWP models, WMO TD N ${ }^{\circ} 1485$, WWRP 2009-1. World Meteorological Organization, Geneva.

Jolliffe, I. \& Stephenson, D. 2012. Forecast verification a practitioner's guide in atmospheric science. John Wiley \& Sons, New Jersey.

Jouanno, J. \& Sheinbaum, J. 2013. Heat balance and eddies in the Caribbean Upwelling System. Journal of Physical Oceanography, 43: 1004-1014. doi: 10.1175/ JPO-D-12-0140.1

Jouanno, J., Sheinbaum, J., Barnier, B., Molines, J., Debreu, L. \& Lemarié, F. 2008. The mesoscale variability in the Caribbean Sea. Part I. Simulations and characteristics with an embedded model. Ocean Modelling, 23: 82-101. doi: 10.1016/j.ocemod.2008. 04.002

Jungclaus, J., Fischer, N., Haak, H., Lohmann, K., Marotzke, J., Matei, D., et al. 2013. Characteristics of the ocean simulations in the Max Planck Institute Ocean Model (MPIOM) the ocean component of the MPI-Earth system model. Journal of Advances in Modeling Earth Systems, 5: 422-446. doi: 10.1002/ jame.20023

Kalnay, E., Kanamitsu, M., Kistler, R., Collins, W., Deaven, D., Gandin, L., et al. 1996. The NCEP/NCAR 40-year reanalysis project. Bulletin of the American Meteorological Society, 77: 437-472. doi: 10.1175/ 1520-0477(1996)077<0437:TNYRP>2.0.CO;2

Kistler, R., Kalnay, E., Collins, W., Saha, S., White, G., Woollen, J., et al. 2001. The NCEP-NCAR 50-year reanalysis: monthly means CD-ROM and documentation. Bulletin of the American Meteorological
Society, 82: 247-268. doi: 10.1175/15200477(2001) 082<0247:TNNYRM>2.3.CO;2

Kessler, W. 2006. The circulation of the eastern tropical Pacific: a review. Progress in Oceanography, 69: 181217. doi: 10.1016/j.pocean.2006.03.009

Kiehl, J., Hack, J., Bonan, G., Boville, B., Briegleb, B., Williamson, D. \& Rasch, P. 1996. Description of the NCAR community climate model (CCM3) NCAR Technical Note NCAR/TN-420+STR. National Center for Atmospheric Research, Colorado. doi: 10.5065/ D6FF3Q99

Large, W., McWilliams, J. \& Doney, S. 1994. Oceanic vertical mixing - a review and a model with a nonlocal boundary-layer parameterization. Reviews of Geophysics, 32: 363-403. doi: 10.1029/94rg01872

Legates, D. \& McCabe Jr., G. 1999. Evaluating the use of "goodness-of-fit" measures in hydrologic and hydroclimatic model validation. Water Resources Research, 35: 233-241. doi: 10.1029/1998WR900018

Lindsey, R. 2013. In watching for El Niño and La Niña, NOAA adapts to global warming. [https://www. climate.gov/print/10421]. Reviewed: April 20, 2020.

Loague, K. \& Green, R. 1991. Statistical and graphical methods for evaluating solute transport models: overview and application. Journal of Contaminant Hydrology, 7: 51-73. doi: 10.1016/0169-7722(91) 90038-3

Locarnini, R., Mishonov, A., Antonov, J., Boyer, T., Garcia, H., Baranova, O., et al. 2013. World ocean atlas 2013, volume 1: temperature. In: Levitus, S. \& Mishonov, A. (Eds.). NOAA Atlas NESDIS 73. NOAA, Maryland.

Lonin, S., Hernández, J. \& Palacios, D. 2010. Atmospheric events disrupting coastal upwelling in the southwestern Caribbean. Journal of Geophysical Research, 115: C06030. doi: 10.1029/2008JC005100

Machu, E., Goubanova, K., Le Vu, B., Gutknecht, E. \& Garçon, V. 2015. Downscaling biogeochemistry in the Benguela Eastern Boundary Current. Ocean Modelling, 90: 57-71. doi: 10.1016/j.ocemod.2015.01.003

Magaña, V., Amador, J. \& Medina, S. 1999. The midsummer drought over Mexico and Central America. Journal of Climate, 12: 1577-1588. doi: 10.1175/15200442(1999)012<1577:TMDOMA >2.0.CO;2

Maldonado, T., Rutgersson, A., Alfaro, E., Amador, J. \& Claremar, B. 2016. Interannual variability of the midsummer drought in Central America and the connection with sea surface temperatures. Advances in Geosciences, 42: 35-50. doi: 10.5194/adgeo-42-352016

Malikov, I. \& Villegas, N. 2010. Proceso de mezcla vertical en las masas de agua de la cuenca del Pacífico 
colombiano y comportamiento anual de sus características termohalinas. Geología Colombiana, 35: 102112.

Malikov, I., Villegas, N. \& Moreno, J. 2010. Identificación de masas de agua horizontales y verticales como base para la localización de estaciones de monitoreo océano-atmosférico en la cuenca del Pacífico colombiano. Investigación, Biodiversidad y Desarrollo, 29: 68-78. doi: 10.18636/RIBD.V29I1. 315.G304

Marchesiello, P., McWilliams, J. \& Shchepetkin, A. 2001. Open boundary conditions for long-term integration of regional oceanic models. Ocean Modelling, 3: 1-20. doi: 10.1016/S1463-5003(00)00013-5

Marsland, S., Haak, H., Jungclaus, J., Latif, M. \& Röske, F. 2003. The Max Planck Institute global ocean/seaice model with orthogonal curvilinear coordinates. Ocean Modelling, 5: 91-127. doi: 10.1016/S14635003(02)00015-X

Mayer, D. \& Butler, D. 1993. Statistical validation. Ecological Modelling, 68: 21-32. doi: 10.1016/03043800(93)90105-2

Medina-Peralta, S., Vargas-Villamil, L., Navarro-Alberto, J., Canul-Pech, C. \& Peraza-Romero, S. 2010. Comparación de medidas de desviación para validar modelos sin sesgo, sesgo constante o proporcional. Universidad y Ciencia, 26: 255-263.

Navia, J., Garavito, J., Rodríguez, A. \& Villegas, N. 2015. Determinación de las capas isotérmica y activa, contenido y flujo de calor en aguas oceánicas de la cuenca del Pacífico colombiano. Boletín Científico CIOH, 33: 39-51. doi: 10.26640/22159045.277

Oleson, K., Niu, G., Yang, Z., Lawrence, D., Thornton, P., Lawrence, P., et al. 2008. Improvements to the community land model and their impact on the hydrological cycle. Journal of Geophysical Research, 113: G01021. doi: 10.1029/2007JG000563

Ortiz-Royero, J., Otero, L., Restrepo, J., Ruiz, J. \& Cadena, M. 2013. Cold fronts in the Colombian Caribbean Sea their relationship to extreme wave events. Natural Hazards and Earth System Sciences, 13: 2797- 2804.

Pal, J., Small, E. \& Eltahir, E. 2000. Simulation of regional-scale water and energy budgets: representation of subgrid cloud and precipitation processes within RegCM. Journal of Geophysical Research, 105: 29579-29594. doi: 10.1029/2000JD900415

Pareja, L., Díaz, D., Rodríguez, A., Villegas, N. \& Pérez, I. 2013. Análisis del transporte y bombeo de Ekman en el Caribe Colombiano entre 1999 y 2009. Boletín Científico CIOH, 31: 3-12. doi: 10.26640/22159045. 248
Paulson, C. \& Ragkousis, G. 2015. pyKriging: A Python Kriging Toolkit (Version v0.1.0-alpha). Zenodo. [https://zenodo.org/record/21389\#.YGuTqThKjIV]. Reviewed: July 24, 2015.

Penven, P., Marchesiello, P., Debreu, L. \& Lefevre, J. 2008. Software tools for pre-and post-processing of oceanic regional simulations. Environmental Modelling \& Software, 23: 660-662. doi: 10.1016/j.envsoft. 2007.07.004

Pérez, J. \& Calil, P. 2017. Regional turbulence patterns driven by meso- and submesoscale processes in the Caribbean Sea. Ocean Dynamics, 67: 1217-1230. doi: 10.1007/s10236-017-1079-7

Poveda, G. \& Mesa, O. 2000. On the existence of Lloro (the rainiest locality on Earth): enhanced ocean-landatmosphere interaction by a low-level jet. Geophysical Research Letters, 27: 1675-1678. doi: 10.1029/1999 GL006091

Poveda, G., Jaramillo, L. \& Vallejo, L. 2014. Seasonal precipitation patterns along pathways of South American low-level jets and aerial rivers. Water Resources Research, 50: 98-118. doi: 10.1002/2013 WR014087.

Poveda, G., Waylen, P. \& Pulwarty, R. 2006. Annual and interannual variability of the present climate in northern South America and southern Mesoamerica. Palaeogeography, Palaeoclimatology, Palaeoecology, 234: 3-27. doi: 10.1016/j.palaeo.2005.10.031

Restrepo, J. 2006. Aporte de caudales de los ríos Baudó, San Juan, Patía y Mira a la cuenca pacífica colombiana. Boletín Científico CCCP, 13: 17-32.

Restrepo, J. \& Kjerfve, B. 2004. The Pacific and Caribbean rivers of Colombia: water discharge, sediment transport, and dissolved loads. In: Lacerda, L., Santelli, R., Duursma, E. \& Abrao, J. (Eds.). Environmental geochemistry in tropical and subtropical environments. Springer, Berlin, pp. 169-187.

Restrepo, J., Pierini, J., Ortíz, J., Schrottke, K., Maza, M., Otero, L. \& Aguirre, J. 2014. Freshwater discharge into the Caribbean Sea from the rivers of northwestern South America (Colombia): magnitude, variability and recent changes. Journal of Hydrology, 509: 266-281. doi: 10.1016/j.jhydrol.2013.11.045

Ricaurte-Villota, C. \& Bastidas-Salamanca, M. 2017. Regionalización oceanográfica: una visión dinámica del Caribe. INVEMAR Ediprint S.A.S., Santa Marta.

Rodríguez, L. 2011. Identificación de zonas homogéneas en la interface mar-aire del mar Caribe colombiano y relación entre la variabilidad de parámetros oceánicos y atmosféricos de algunos puntos representativos de estas zonas y la oscilación Atlántico Norte. Tesis de Magíster, Universidad Nacional de Colombia, Bogotá. 
Rodríguez-Rubio, E., Schneider, W. \& Abarca Del Rio, R. 2003. On the seasonal circulation within the Panama Bight derived from satellite observations of wind, altimetry, and sea-surface temperature. Geophysical Research Letters, 30: 1410. doi: 10.1029/2002GL 016794.

Rodríguez, L., Villegas, N. \& Malikov, I. 2010. Análisis espacial y temporal de las variables oceánicas y atmosféricas del mar Caribe colombiano. Meteorología Colombiana, 14: 69-78.

Roeckner, E., Bäuml, G., Bonaventura, L., Brokopf, R., Esch, M., Giorgetta, M., et al. 2003. The atmospheric general circulation model ECHAM5. Part I: model description, report 349. Max-Planck-Institut für Meteorologie, Hamburg.

Rueda-Roa, D. \& Muller-Karger, F. 2013. The southern Caribbean upwelling system: sea surface temperature, wind forcing and chlorophyll concentration patterns. Deep-Sea Research I: Oceanographic Research Papers, 78: 102-114. doi: 10.1016/j.dsr.2013.04.008

Rueda, O. \& Poveda, G. 2008. Variabilidad espacial y temporal del chorro del Chocó y su efecto en la hidroclimatología de la región del pacífico colombiano. Meteorología Colombiana, 10: 132-145.

Ruiz-Ochoa, M., Beier, E., Bernal, G. \& Barton, E. 2012. Sea surface temperature variability in the Colombian Basin, Caribbean Sea. Deep-Sea Research I: Oceanographic Research Papers, 64: 43-53. doi: 10.1016/j. dsr.2012.01.013

Shchepetkin, A. \& McWilliams, J. 2005. The regional oceanic modeling system (ROMS): a split-explicit, free-surface, topography-following-coordinate oceanic model. Ocean Modelling, 9: 347-404. doi: 10.1016/ j.ocemod.2004.08.002

Shchepetkin, A. \& McWilliams, J. 2009. Correction and commentary for "ocean forecasting in terrainfollowing coordinates: formulation and skill assessment of the regional ocean modeling system" by Haidvogel et al. J. Comp. Phys, 227: 3595-3624. Journal of Computational Physics, 228: 8985-9000. doi: 10.1016/j.jcp.2009.09.002

Sierra, P., Arias, P. \& Vieira, S. 2015. Precipitation over Northern South America and its seasonal variability as simulated by the CMIP5 models. Advances in Meteorology, 634720. doi: 10.1155/2015/634720

Sierra, P., Arias, P., Vieira, S. \& Agudelo, J. 2018. How well do CMIP5 models simulate the low-level jet in western Colombia? Climate Dynamics, 51: 22472265. doi: 10.1007/s00382-017-4010-5

Sitz, L., Di Sante, F., Farneti, R., Fuentes-Franco, R., Coppola, E., Mariotti, L., et al. 2017. Description and evaluation of the Earth System Regional Climate Model (Reg CM-ES). Journal of Advances in
Modeling Earth Systems, 9: 1863-1886. doi: 10.1002/ 2017MS000933

Slutz, R., Lubker, S., Hiscox, J., Woodruff, S., Jenne, R., Joseph, D., et al. 1985. Comprehensive oceanatmosphere data set: release 1. [http://icoads.noaa.gov/ Release_1/coads.html]. Reviewed: October 2, 2020.

Smith, W. \& Sandwell, D. 1997. Global seafloor topography from satellite altimetry and ship depth soundings. Science, 277: 1956-1962. doi: 10.1126/ science. 277.5334 .1956

Stevens, B., Giorgetta, M., Esch, M., Mauritsen, T., Crueger, T., Rast, S., et al. 2013. Atmospheric component of MPI-M Earth System Model: ECHAM6. Journal of Advances in Modeling Earth Systems, 5: 146-172. doi: 10.1002/jame.20015

Stevenson, M. 1970. Circulation in the Panama Bight. Journal of Geophysical Research, 75: 659-672. doi: 10.1029/JC075i003p00659

Strub, P., Mesias, J., Montecino, V., Rutllant, J. \& Salinas, S. 1998. Coastal ocean circulation off western South America. In: Robinson, A. \& Brink, K. (Eds.). Global Coastal Ocean. Interscience, New York, pp. 273-313.

Taylor, M., Whyte, F., Stephenson, T. \& Campbell, J. 2013. Why dry? Investigating the future evolution of the Caribbean low-level jet to explain projected Caribbean drying. International Journal of Climatology, 33: 784-792. doi: 10.1002/joc.3461

Tedeschi, L. 2006. Assessment of the adequacy of mathematical models. Agricultural Systems, 89: 225247. doi: 10.1016/j.agsy.2005.11.004

Trojer, H. 2017. Meteorología y climatología de la vertiente del Pacífico colombiano. Revista de la Academia Colombiana de Ciencias Exactas, Físicas y Naturales, 41: 467-490. doi: 10.18257/raccefyn.583

Turuncoglu, U., Giuliani, G., Elguindi, N. \& Giorgi, F. 2013. Modeling the Caspian Sea and its catchment area using a coupled regional atmosphere-ocean model (RegCM4-ROMS): model design and preliminary results. Geoscientific Model Development, 6: 283299. doi: 10.5194/gmd-6-283-2013

Veloza, D. 2017. Definición del clima del Caribe colombiano desde San Lorenzo (Magdalena) hasta Manaure (Guajira) por medio del análisis de datos meteorológicos de los últimos 30 años. Tesis de Bachiller, Universidad Nacional de Colombia, Bogotá.

Villegas, N. \& Malikov, I. 2006. Modelación de la estructura dinámica de las aguas de la Cuenca del Pacífico Colombiano. Boletín Científico Centro de Control de Contaminación del Pacífico, 13: 97-114.

Villegas, N. \& Malikov, I. 2009. Atlas de las características termohalinas y dinámicas de las aguas de la 
Cuenca del Pacífico Colombiano: con base en simulación matemática. Unibiblios, Bogotá.

Villegas, N., Malikov, I. \& Díaz, D. 2016. Variabilidad mensual de la velocidad de surgencia y clorofila a en la región del Panama Bight. Revista Mutis, 6: 82-94. doi: $10.21789 / 22561498.1153$

Villegas, N., Malikov, I. \& Rodríguez, A. 2013. Comparación de temperatura superficial del mar simulada y datos ICOADS del Caribe y Pacífico Colombianos. Libro de Resúmenes XV SENALMAR. Invemar, Santa Marta.

Wallace, J., Mitchell, T. \& Deser, C. 1989. The influence of sea surface temperature on surface wind in Eastern Equatorial Pacific: seasonal and interannual variability. Journal of Climate, 2: 1492-1499. doi: 10.1175/ 1520-0442(1989)002<1492:TIOSST>2.0.CO;2

Wang, C. 2007. Variability of the Caribbean low-level jet and its relations to climate. Climate Dynamics, 29: 411-422. doi: 10.1007/s00382-007-0243-Z

Wetzel, P., Haak, H., Jungclaus, J. \& Maier-Reimer, E. 2010. The Max-Planck-Institute Global Ocean/Sea-Ice model MPI-OM. Max-Planck-Institut für Meteorologie, Hamburg.

Whyte, F., Taylor, M., Stephenson, T. \& Campbell, J. 2008. Features of the Caribbean low-level jet. International Journal of Climatology, 28: 119-128. doi: 10.1002/joc. 1510

Wilks, D. 2011. Statistical methods in the atmospheric sciences. Academic Press, Cambridge.

Received: April 15, 2019; Accepted: January 25, 2021
Willmott, C., Ackleso, S., Davis, R., Feddema, J., Klink, K., Legates, D., et al. 1985. Statistics for the evaluation and comparison of models. Journal of Geophysical Research, 90: 8995-9005. doi: 10.1029/JC090iC05 p08995

Wooster, W. 1959. Oceanographic observations in the Panama Bight, "ASKOY" Expedition, 1941. Bulletin of the American Museum of Natural History, 118: 113-152.

Xue, Y., Smith, T. \& Reynolds, R. 2003. Interdecadal changes of 30-Yr SST normals during 1871-2000. Journal of Climate, 16: 1601-1612. doi: 10.1175/15200442(2003)016<1601:ICOYSN>2.0.CO;2

Zhang, W., Li, J. \& Zhao, X. 2010. Sea surface temperature cooling mode in the Pacific cold tongue. Journal of Geophysical Research, 115: C12042. doi: 10.1029/2010JC006501

Zheng, Y., Lin, J. \& Shinoda, T. 2012. The equatorial Pacific cold tongue simulated by IPCC AR4 coupled GCMs: upper ocean heat budget and feedback analysis. Journal of Geophysical Research, 117: C05024. doi: 10.1029/2011JC007746

Zweng, M., Reagan, J., Antonov, I., Locarnini, R., Mishonov, A., Boyer, T., et al. 2013. World ocean atlas 2013, volume 2: Salinity. In: Levitus, S. \& Mishonov, A. (Eds.). NOAA Atlas NESDIS 74. NOAA, Maryland. 